\title{
Seasonal and site-specific
} variability in terrigenous particulate organic carbon concentration in near-shore waters of Lake Biwa, Japan

\section{$\operatorname{AUTHOR}(S)$ :}

Sakai, Yoichiro; Karube, Zin'ichi; Takeyama, Tomohiro; Kohzu, Ayato; Yoshimizu, Chikage; Nagata, Toshi; Tayasu, Ichiro; Okuda, Noboru

\section{CITATION:}

Sakai, Yoichiro ... [et al]. Seasonal and site-specific variability in terrigenous particulate organic carbon concentration in near-shore waters of Lake Biwa, Japan. Limnology 2013, 14(2): 167-177

\section{ISSUE DATE:}

2013-04

URL:

http://hdl.handle.net/2433/173518

\section{RIGHT:}

The final publication is available at link.springer.com; この論文は出版 社版でありません。引用の際には出版社版をご確認ご利用ください。; This is not the published version. Please cite only the published version. 
1 Title

2 Seasonal and site-specific variability in terrigenous particulate organic carbon

3 concentration in near-shore waters of Lake Biwa, Japan

4

5 Authors

$6 \quad{ }^{1}$ Sakai Y, ${ }^{2}$ Karube Z, ${ }^{3}$ Takeyama T, ${ }^{2}$ Kohzu A, ${ }^{1}$ Yoshimizu C, ${ }^{4}$ Nagata T, ${ }^{1}$ Tayasu I and

$7 \quad{ }^{1}$ Okuda $\mathrm{N}$

8

$9{ }^{1}$ Center for Ecological Research, Kyoto University, 509-3, 2-chome, Hirano, Otsu,

10 Shiga 520-2113, Japan

$11{ }^{2}$ National Institute for Environmental Studies, 16-2 Onogawa, Tsukuba-City, Ibaraki,

12 305-8506, Japan

$13{ }^{3}$ Department of Biology and Geosciences, Osaka City University, 3-3-138 Sugimoto,

14 Sumiyoshi, Osaka, 558-8585, Japan

$15{ }^{4}$ Atmosphere and Ocean Research Institute, The University of Tokyo, Kashiwa, Chiba,

16 277-8564, Japan

17

18 Correspondence: Yoichiro SAKAI 
19 Center for Ecological Research, Kyoto University, 509-3, 2-chome, Hirano, Otsu, Shiga

20 520-2113, Japan.

21 Tel: 077-549-8020

22 Fax: 077-549-8201

23 E-mail: biwaensis.2002@gmail.com

24 
26 Abstract

Identifying sources of particulate organic matter $(\mathrm{POM})$ is important for

clarifying fundamental mechanisms by which lake food webs are sustained. We

determined carbon and nitrogen stable isotope ratios of POM in near-shore waters of

Lake Biwa, a large, meso-eutrophic lake in Japan, to estimate relative contributions of

terrigenous particulate organic carbon (T-POC), plankton-derived POC (P-POC), and

epilithon-derived POC (E-POC) to POC in near-shore waters. Samples were collected

during different months (November, February, May and July) at 29sites located near the

mouth of tributary rivers with different discharge and catchment land use. The data

revealed that POC mainly consisted of P-POC and T-POC, with relative contributions

varying widely over season and among locations. E-POC generally contributed little to

the near-shore POC. Path analyses revealed that concentration of riverine POC whose

field area in the catchment of tributary rivers, which subsequently enhanced T-POC

inputs to near-shore waters through riverine transportation. Furthermore, our results 
$45 \quad$ Keywords

46 Allochthonous input, Isotope mixing model, Land use, Path analysis, Terrigenous POM

47 
Introduction Particulate organic matter (POM) is a fundamental energy source for food webs in lake ecosystems. POM in lake waters consists of diverse organic compounds with different origins, including phytoplankton-derived POM (P-POM), epilithon-derived POM (E-POM) and terrigenous POM (T-POM). Although P-POM is generally considered to be a major energy source for planktonic food webs in pelagic environments (Dodson 2005), E-POM and T-POM may also play an important role as food resources for suspension feeders. In fact, in small to medium-sized lakes in North America, some studies have revealed that terrigenous particulate organic carbon (T-POC) derived from tributary rivers can subsidize pelagic food webs (Cole et al. 2006; Pace et al. 2007; Cole et al. 2011). Other studies, however, have suggested that zooplankton growth and reproduction is slowed by the inputs of T-POM, which have high C/N ratios and area low-quality food (Karlsson 2007; Brett et al. 2009). In other systems, it has been reported that pelagic food webs were subsidized by benthic algal products (Rautio and Vincent 2007; Karlsson and Sawstrom 2009). For aquatic consumers, reliance on each of POM originated from different sources appears to vary widely among lakes, depending on lake size, depth and trophic status (Chandra et al. 
different origins may also vary among different locations of a single lake, especially in

68 near-shore waters. For example, allochthonous input of T-POM might be large in near-shore environments adjacent to river mouths, although the extent and nature of this "river effect" may depend on river discharge, T-POM concentrations in river waters, and physical settings of the locations (shore topography and turbulence that affect sedimentation and resuspension of T-POM). Spatial and temporal variability in contributions of POM with different origins within a single lake has important implications for understanding mechanisms by which lake food webs are differentially organized in the same species pool. Indeed, a previous work has reported that allochthonous organic matter inputs to Lake Biwa from tributary catchments led to spatial heterogeneity in trophic pathways within coastal macro-invertebrate communities (Karube et al. 2010). However, data are highly limited to elucidate mechanisms underlying spatio-temporal variability in relative contributions of P-POM, T-POM and E-POM to total POM in near-shore environments. Here, we measured carbon $\left(\delta^{13} \mathrm{C}\right)$ and nitrogen $\left(\delta^{15} \mathrm{~N}\right)$ stable isotope ratios of POM in near-shore water samples collected during four seasons at different locations set along the shore-line of Lake Biwa. In general, $\mathrm{C}_{3}$ terrestrial plants (T-POM) have markedly different $\delta^{13} \mathrm{C}(-27 \%)$ from that of aquatic microalgae (P-POM and E-POM; 
85 Marshall et al. 2007). Moreover, among aquatic primary producers, phytoplankton and

86

epilithic algae have different $\delta^{13} \mathrm{C}$, due to the $\mathrm{CO}_{2}$ diffusion limitation within the boundary layer surrounding algal cells (Phytoplankton: $-32 \pm 2$ (SD) \%o, epilithic algae:

$-17 \pm 2(\mathrm{SD}) \%$; Fry and Sherr 1984 ; France 1995$)$. In addition, $\delta^{15} \mathrm{~N}$ of aquatic primary producers may be variable among aquatic environments depending on the extent of anthropogenic nitrogen inputs (McClelland and Valiela 1998; Kohzu et al. 2008; Karube et al. 2010). The above differences in isotope signatures of POM with different origins are useful for estimating the relative contribution of P-POM, E-POM and T-POM by means of stable isotope mixing models (Fry 2006).

Lake Biwa, the largest lake in Japan, consists of two basins: the large (616 $\mathrm{km}^{2}$ ), deep (average depth $41 \mathrm{~m}$ ), mesotrophic northern basin and the small $\left(58 \mathrm{~km}^{2}\right)$, shallow (average depth 4 m), eutrophic southern basin (Rossiter 2000; Somiya 2000). The lake receives water from 121 major tributary rivers and hundreds of other small creeks. The catchments of the major rivers show a wide range of land use patterns, including those prevailed by agricultural field, forest, or residence area (Somiya 2000). The 29 sampling sites of the present study covered a range of situations with variable influences of rivers that have different land use patterns in their catchments. We hypothesize that the quantity and composition of the near-shore POM can vary, on a 
within-lake scale, depending on land use patterns in tributary catchments as well as on coastal physical characteristics. Assuming that POM with different origins, i.e., P-POM, E-POM and T-POM, have different stable isotopic signatures, we aim to examine what factors determine within-lake variability in relative contributions of these potential organic sources to the near-shore POM, using an isotope mixing model and a path analysis.

Materials and Methods

Sample collections

We collected POM samples at 29 sites along the shoreline of Lake Biwa in November2005 and February 2006, May 2006, and July 2006 (Fig. 1). These sites were located near the mouth of tributary rivers, which have widely variable land use patterns (Appendix A). In most cases, the sampling sites were set within $100 \mathrm{~m}$ of the river mouth. For some sites, however, our research boat could not get access to the target location because these sites have a gentle coastal slope and/or are luxuriated by submerged plants. In such cases, the sampling site was set on the position of $5 \mathrm{~m}$-depth contour where the distance between the site and river mouth was shortest. We measured $\mathrm{pH}$ and electric conductivity using a multiprofiler at each sampling site (U-22, 
HORIBA).

At each sampling site, we used a water pump to collect water samples at the depth of $2 \mathrm{~m}$. The water samples were first filtered through a $150 \mu \mathrm{m}$-mesh net to remove coarse particles and then filtered through precombusted $\left(450^{\circ} \mathrm{C}\right.$ for $\left.2 \mathrm{~h}\right)$ glass fiber filters (GF/F, $0.7 \mu \mathrm{m}$, Whatman). The particle size of $0.7-150 \mu \mathrm{m}$ covers the most size range of phytoplankton found in Lake Biwa (Tsuda et al. 1992). The POMs collected on the glass fiber filters were used for stable isotope analysis (see below). We extracted Chlorophyll $a$ from these POM samples in 90\% acetone solution and measured its concentration with a fluorometer (Turner Designs, 10-AU), according to Wetzel and Linkens (2000). The Chlorophyll $a$ concentration was used as an indicator of local productivity in near-shore waters.

We assumed three end members (plankton, epilithon and terrigenous organic matter) as primary organic sources for the near-shore POM. First, to determine isotopic values of plankton-derived POM (P-POM), we collected water samples from the depth of $2 \mathrm{~m}$ at an offshore site (Station 30, see Fig. 1) in the same months as POM sampling in near-shore waters. The P-POM was filtered on precombusted GF/F filters after screening with a $150 \mu \mathrm{m}$-mesh net. The P-POM collected at this site was assumed to have isotope signatures typical for phytoplankton-derived organic matter in the lake 
139 because previous work has found that $\delta^{13}$ Cvalues of POM collected there were identical

140 to those of chlorophyll $a$ extracted from offshore phytoplankton after the correction of

141 isotope fractionation (Maki et al. 2010).

epilithon samples were collected at all the sites except for some sites where boulders of off, with a brush, from five boulders of moderate size $(30-40 \mathrm{~cm})$ which have a surface area of more than $36 \mathrm{~cm}^{2}$ on the upper side were mixed, filtered through precombusted

$147 \mathrm{GF} / \mathrm{F}$ filters, and served for the stable isotope analyses.

149 terrigenous POM (T-POM) at sites $0.5-4 \mathrm{~km}$ upstream from the mouth, in the same

150 months as the near-shore sampling but in the previous year (i.e., July 2004, November 
157 T-POM, Nov: $\mathrm{p}=0.82$, Feb: $\mathrm{p}=0.65$, May: $\mathrm{p}=0.79$, Jul.: $\mathrm{p}=0.91$ ), suggesting that R-POM

158 is dominated by T-POM in tributary rivers of Lake Biwa.

One may expect that submerged macrophytes can be a dominant source for the

near-shore POM. However, we did not incorporate them as an end member of our

mixing model for the following reasons. First, live macrophytes cannot contribute to the

POM pool in near-shore waters during summer growing season. It may be true that their

detritus contribute to the near-shore POM during decomposition process in winter,

especially at sampling sites in shallow south basin where macrophytes luxuriate

vigorously (Haga et al. 2007). However, we have little knowledge on stable isotopic

fractionation during their decomposition and have technical difficulty in separate their

detritus from a mixture of POM with different origins in the near-shore waters for the

stable isotope analysis. If macrophyte contribution is not much great for near-shore

waters of whole lake basin, we have a disadvantage to incorporate additional end

member into our mixing model, which will lead to low estimation accuracy for major

organic sources. Therefore, we did not regard submerged macrophytes as primary

organic sources in the near-shore water. 
composition of near-shore POM. All these POM samples collected on precombusted

$\mathrm{GF} / \mathrm{F}$ filters were exposed to $0.1 \mathrm{M} \mathrm{HCl}$ to eliminate carbonates, rinsed with distilled water, and then stored at $-20^{\circ} \mathrm{C}$ until the stable isotope analysis.

Stable isotope analysis

scraped off from the surface of filters. Carbon and nitrogen stable isotope ratios of the

residues were determined using continuous-flow isotope ratio mass spectrometers

XP, Thermo Fisher, Germany)and their carbon content was measured using elemental

ratios were expressed as the per mil deviation from standards as follows:

$$
\delta^{13} \mathrm{C} \text { or } \delta^{15} \mathrm{~N}=\left(\mathrm{R}_{\text {sample }} / \mathrm{R}_{\text {standard }}-1\right) \times 1000(\%),
$$

where $\mathrm{R}={ }^{13} \mathrm{C} /{ }^{12} \mathrm{C}$ or ${ }^{15} \mathrm{~N} /{ }^{14} \mathrm{~N}$. Vienna Pee Dee belemnite (VPDB) and atmospheric and $\delta^{15} \mathrm{~N}$. 
Isotope mixing model and T-POM) to POM collected at each near-shore site were estimated using an isotope mixing model with $\delta^{13} \mathrm{C}$ and $\delta^{15} \mathrm{~N}$ (IsoSource Program; Phillips and Gregg 2003). This model enabled us to estimate all possible combinations of each source contribution $(0-100 \%)$ in $1 \%$ increments to create a set of predicted sources. The initial tolerance was set at $0.1 \%$. If the estimated values were outliers (i.e., $<0 \%$ or $>100 \%$ ), the tolerance was increased in $0.1 \%$ steps to $2 \%$. The model outputs are expressed as the mean value and range (minimum-maximum) for each source. From the estimated mean contribution of each organic carbon source to POC concentration $\left(\mathrm{mgL}^{-1}\right)$ at each near-shore site, we calculated the concentrations of P-POC, E-POC and T-POC according to the following equation.

$$
\mathrm{T}-\mathrm{POC}\left(\mathrm{mgL}^{-1}\right)=\mathrm{POC}\left(\mathrm{mgL}^{-1}\right) \times f_{\mathrm{t}}
$$

where $f_{\mathrm{p}}, f_{\mathrm{e}}$ and $f_{\mathrm{t}}$ are the fraction of P-POC, E-POC and T-POC relative to the near-shore POC (i.e., $\left.f_{\mathrm{p}}+f_{\mathrm{e}}+f_{\mathrm{t}}=1\right)$. 
211 E-POC data or because the estimated contribution remained outlier for either of the

212 three sources under the above criteria for our isotopic mixing model. In the present

213 study, we present results of simulation model only for carbon source estimation but

214 analytical results on nitrogen sources were qualitatively same as the carbon source

215 estimation model.

216

217 Land use pattern and physical environments

219 paddy field, forest, and residential areas of tributary catchment were calculated using a geographical information system (GIS: Appendix A). We assumed that these indices reflect the loading of terrigenous organic matter with different origins: e.g., the HPD or \%residential area is an indicator of organic matter derived from sewage, the \%paddy field area is an indicator of that from agricultural wastewater, and the \%forest area an indicator of that from leaf litter transported through upper streams.

Because there is a strong positive correlation between river discharge and catchment area, we estimated the river discharge, based on the following regression for tributary rivers for which discharge data are available (Shiga Prefecture1992-2002): River discharge $\left(\mathrm{m}^{3} \mathrm{~S}^{-1}\right)=0.0284 \times$ catchment area ${ }^{0.9502}\left(\mathrm{R}^{2}=0.846, \mathrm{p}<0.01\right)$ 
229 where the river discharge is the average for February, May, July, and November during

230 the recent 10 years (1992-2002).Although the river discharge shows daily variation

231 depending on weather condition, its monitoring date never accorded with our sampling

232 date. Considering this variation, the inter-annual average can be a better indicator for

233 river discharge compared to single monitoring data corresponding to our sampling

234 months.

As physical characteristics of coastal environments, we used wave height (m),

236 wave energy flux $\left(\mathrm{kg} \mathrm{m}\right.$ day $\left.^{-1} \mathrm{~m}^{-1}\right)$, shore energy flux $\left(\mathrm{kg} \mathrm{m}\right.$ day ${ }^{-1} \mathrm{~m}^{-1}$, see Nakatsuji et al.

237 2006), and coastal slope $\left(1 \mathrm{~d}^{-1} ; \mathrm{d}=\right.$ horizontal distance from the shoreline to the point

238 with a depth of $2 \mathrm{~m}$ ). These data are available at

239 http://www.biwakokasen.go.jp/others/kankyoujyouhou/index.html (Kinki Regional

240 Development Bureau, Ministry of Land, Infrastructure, Transport and Tourism).

241 The GIS and coastal physical characteristics data are summarized in Appendix A and B.

Statistical analysis

We performed a nested analysis of variance (ANOVA) to test the temporal 
247 error term distribution accords to gaussian distribution. If the data distribution did not

248 show normality and homoscedasticity, the dependent variable (POC concentration) was

$249 \log (\mathrm{x}+0.5)$-transformed satisfy the criteria for the ANOVA (Yamamura 1999). Then we

250 performed a post-hoc test for multiple comparisons using the Tukey method (the

251 multcomp package of R Statistics; Hothorn et al. 2008) to compare POC concentrations

252 among seasons. Furthermore, we performed ANOVA to compare the carbon

253 concentrations among the three organic sources (P-POC, E-POC, and T-POC) in each

254 season. All analyses were conducted using the statistical package R ver. 2.13.1 (R

255 Development Core Team 2011).

256

We performed a path analysis to examine how the land use patterns in the

257 tributary catchments and the physico-chemical characteristics of the sampling sites may

258 affect spatiotemporal variation in measured and estimated values of R-POC and T-POC

259 concentrations, respectively, incorporating GIS and environmental variables into the

260 model (see Appendix A and B). First, we screened the explanatory variables because

261 models with too many variables generate redundant information. We checked the

correlations among variables to remove multicollinearity and then selected the variables

that best accounted for the variation in R-POC and T-POC concentrations. For instance, 
not \%residential area. Because forest and paddy field are the most dominant land use

types in the Lake Biwa Watershed, it is a matter of course that there is a strong negative correlation between their proportional data $\left(\mathrm{R}^{2}=0.93, \mathrm{p}<0.001\right)$. We performed two preliminary models to test effects on the R-POC for each of these two land use types.

First, when we used \%forest area solely as a GIS variable, instead of \%paddy field area, we found that the former showed significantly negative but not positive effects (Path coefficients, Nov.: -0.44, Feb.: -0.53, May: -0.83, Jul.: -0.64, p<0.01). Second, when we incorporated residuals of the \%forest area regressed against the \%paddy field area into the preliminary model, we did not find any significantly positive effect of \%forest area on R-POC concentration, suggesting that forests cannot be a primary source of R-POC loadings in catchment areas. Based on results of these preliminary analyses, therefore, we excluded \%forest area from a final version of our a priori model to reduce the redundancy and the multicollinearity between potentially correlated GIS variables. After screening the variables, we constructed the basic framework of an $a$ priori model consisting of two components (Fig. 3). The model was separated because the data distributions were needed to be $\log (\mathrm{x}+0.5)$-transformed for some of explanatory variables in component 2 to ensure normality and homoscedasticity for statistical criteria. Component 1 was a sub-model that accounts for the variation in measured 
283 values of R-POC (upper panel in Fig. 3). Assuming that human sewage and agricultural

284 wastewater have strong effects on R-POC, we incorporated HPD (Path 1 in Fig. 2) and

285 the \%paddy field area (Path 2) into the model. We also assumed that the HPD

286 and \%paddy field areas have a positive interactive effect because agricultural activities

287 are usually high in areas with a high population density and vice versa (Path 3 ).

288

Component 2 was constructed to examine which physical characteristics of

289 coastal environments explain the site-specific variation in estimated values of T-POC

290 concentration in near-shore waters, assuming that T-POC concentration can be affected

291 by a dilution effect due to river discharge (Path 5), resuspension due to wave-driven

292 turbulence (Path 6), and the potential for resuspension, which is intensified in sites with

293 a gentle coastal slope (Path 7). These paths were assumed to have an additive effect on

294 T-POC concentration.

The model analysis consisted of two steps. First, we conducted a simultaneous

analysis of several groups, considering the four seasons as different groups. This

allowed us to test for significant differences in the causal mechanisms of the seasonal

dynamics of R-POC and T-POC concentrations and provided more accurate model 
constraints as a null hypothesis that the coefficient of each path is not significantly

different among the four seasons (Tabei 2001; Arbuckle 2007). In the initial condition,

303 the level of significance was set at 0.05 for the seasonal difference in each path

304 coefficient and was then increased up to 0.6 in intervals of 0.05 . In this way, we

305 constructed a total of 12 models and compared them using the Akaike information

criterion (AIC). We selected the best-fit model based on the minimum AIC. The best-fit

307 model was tested using the chi-square goodness-of-fit. We also evaluated its

308 goodness-of-fit based on the root mean square error of approximation (RMSEA;

309 criterion RMSEA < 0.05: good, RMSEA > 0.08: mediocre, RMSER > 0.1: not accepted,

310 Browne and Cudeck 1993). The path analysis was performed using the statistical

311 package AMOS (ver. 16, IBM-SPSS, Tokyo).

313 Results

314 Spatiotemporal variation in POC concentration and composition Using carbon and nitrogen isotope mixing model with three end members,

P-POM, E-POM and R-POM, we estimated the relative contributions of three organic

C\&D). As indicated by a narrow range of estimated values, our isotope mixing model 
319 showed high estimation accuracy (Appendix D), except for some sites (e.g., site no. 3,

$32010,11,13,20$ in November, 2005), in which P-POM and R-POM had similar isotopic

321 signatures (Appendix C). Based on the relative contribution of these sources, we

322 calculated the concentration of P-POC, E-POC, and T-POC (Table 1 \& Fig. 4). The

323 near-shore POC concentrations differed among sites (Fig. 4) and seasons $\left(\mathrm{F}_{3,83}=13.56\right.$,

324 Jul. > May = Feb. > Nov., p < 0.05). P-POC and T-POC were the dominant organic

325 sources of the near-shore POC, whereas E-POC concentration was consistently low (Fig.

326 5). In July, the concentration of P-POC was generally higher than that T-POC (Fig. 5).

327 T-POC concentrations tended to be high at the sites located along southern and eastern

328 shores, especially in February and May (Fig. 4).

329

330 Possible factors that influences the spatiotemporal dynamics of T-POC

variation at sampling sites (Fig. 4). In our path analysis, a sub-model of component 1

$\left(\chi^{2}=0.721, \mathrm{df}=7, \mathrm{RMSEA}=0.000, \mathrm{AIC}=58.721\right)$. The total effect of human land use on 
337 2). In contrast, HPD did not have significantly positive effects on R-POC concentration 338 (Path 1).

Similarly, component 2 of our path model was the best fit when the significance level was set at $0.3\left(\chi^{2}=0.488, \mathrm{df}=42, \mathrm{RMSEA}=0.057, \mathrm{AIC}=140.288\right)$. The total effect of proximate physical factors on T-POC showed great seasonal variation (Fig.

6). The allochthonous input of R-POC had a significantly positive effect on the near-shore T-POC concentration only in May (Path 4), whereas river discharge had a always had a significantly positive effect on the near-shore T-POC concentration (Path 6), and the near-shore T-POC concentration was higher for sites with a gentle coastal slope in February and May (Path 7).

Discussion among sites and over season. The results of path analysis suggested that agricultural wastewater from the paddy fields was the primary driver affecting the near-shore T-POC concentration via increased inputs of R-POC. Especially in May, we detected a significant, robust path in that the \%paddy field area had a positive effect on the 
T-POC in May could be related to agricultural practices in this season. Previous work

has reported that a large quantity of paddy-derived wastewater flows into the lake basin

2002; Haga and Ohtsuka 2003; Ohkubo and Azuma 2005; Hama et al. 2010). The

results of the present study support the notion that agricultural activities, especially paddy irrigation, can be a significant factor that affects T-POC concentrations in area had a positive effect on R-POC concentration even in February when paddy field activities are considered to be minimal. This suggests the possibility that organic-rich soils can be eroded from paddy fields even in winter, due to snowing and melting.

Although the underlying mechanisms have not yet been poorly understood, they remain to be investigated in the future. coastal environment, including coastal slope and wave height, have significant effects on T-POC concentration in near-shore waters. We speculate that waves and gentle coastal slopes might synergistically enhance the resuspension of sedimentary T-POC, resulting in increased terrestrial contribution to the near-shore POC. This notion is 
partly supported by findings of Murase and Sakamoto (2000) who reported that the

near-shore sediments of Lake Biwa contained a large quantity of terrigenous organic

matter. Intriguingly, in the present study, although R-POC had a positive effect on

November, after rice field irrigation season (Fig. 6). These results suggest that

sedimentation and wave-driven resuspension in near-shore waters.

discharge, as well as by its concentration. However, our analysis did not support this

prediction and revealed that river discharge had strongly negative effects on the

near-shore T-POC concentrations in July with high precipitation. In general, flooding

has the potential to increase concentration of suspended organic matter in river water and consequently organic matter loadings on near-shore waters. However, we avoided

field samplings during flooding events because our interest was in land use effects on

allochthonous inputs but not in physical transportation mechanisms under ordinary flow

conditions. During the rainy season, discharge of larger rivers which receive larger 
T-POC, whereas E-POC contributed little to POC regardless of the season and site. In

some shallow and oligotrophic lakes, it has been reported that epilithic-derived trophic

Sawstrom 2009). There are two possible mechanisms in which relative contribution of

397 features: Lake Biwa has a deep structure with a steep slope, especially for large north basin, in which the proportional area of shallow waters to the whole basin was considerably small (Sakamoto 2000), suggesting that habitats are limited for epilithic growth. Another mechanism is that an increase in P-POM and T-POM decreases light penetration to the lake bottom, which has negative effects on epilithic growth (Vadeboncoeur et al. 2001, 2003). Consistent with our observation, previous studies have reported that filter-feeding macrozoobenthos and zooplankton in near-shore environments of Lake Biwa relied mainly on P-POC and T-POC rather than on E-POC (Karube et al. 2010). Their production reliance is also trophically transferred to that of predatory fishes, characterizing food web configuration of whole communities (Okuda et al. 2012). 
the near-shore POM for the following two reasons. First, in Lake Biwa, especially in

disproportionately small relative to that of the whole basin, so that their total primary euphotic zone is deeper than the macrophytes (Sakamoto 2000). Second, we have technical difficulty in separating macrophyte detrital fraction from a mixture of POM with different origins in the near-shore water for the stable isotope analysis and thus in characterizing isotopic alteration during their decomposition in nature. To evaluate their

417 contribution, one of promising approaches is polyunsaturated fatty acid (PUFA) analysis,

418 which can quantify each of organic sources by characterizing the composition of

419 primary producer-specific polyunsaturated fatty acids (Kelly and Scheibling2012). In

420 floodplain lakes of the central Brazilian Amazon basin, for instance, the technique revealed that macrophyte detritus is a primary component of suspended POM during low water season (Mortillaro et al. 2011). The application of PUFA analysis, even if it is beyond our scope in the present study, will be a future challenge for better understanding of seasonal changes inorganic matter flows in Lake Biwa, especially in shallow south basin where submerged plants have recently luxuriated. 
427 T-POC to near-shore waters were affected not only by the land use pattern in tributary

428 catchment areas, but also by the physical characteristics of local coastal environments.

429 This suggests that the spatiotemporal heterogeneity of food quality and quantity for

430 aquatic consumers will create a dynamic pattern of coastal food webs, altering the

431 relative importance of autochthonous grazing food chain and allochthonous microbial

432 loop in lake ecosystems.

433

434 Acknowledgments

We are grateful to Dr. T. Koitabashi and Dr. Y. Goda for field assistance. We also thank to Dr. E. Nakajima for useful comments on the manuscript. Dr. T. Ohtsuka provided technical advice on statistics. This study was supported by the JSPS Grant-in Aid (No.23657019 and No.24370010), the CREST project, JST and The Environment Research and Technology Development Fund (D-1102 and S-9) of the Ministry of the Environment, Japan. This study was partly supported by the Research Project 3-1 of The Research Institute for Humanity and Nature. YS, ZK and NO were also supported by

Global COE Program A06 "Formation of a strategic base for biodiversity and 
446 Reference

447 Arbuckle JL (2007) Amos 16.0 User's Guide. Amos Development Corporation, Spring 448 House

449 Brett MT, Kainz MJ, Taipale SJ, Seshan H (2009) Phytoplankton, not allochthonous

450 carbon, sustains herbivorous zooplankton production. Proceedings of the National

451 Academy of Sciences 106:21197-21201

452 Browne M W, and Cudeck R(1993) Alternative ways of assessing model fit. In:Bollen

453 KA and Long JS (ed.) Testing structural equation models, Sage Publications, Newbury

454 Park, pp136-162.

455 Chandra S, Vander Zanden MJ, Heyvaert AC, Richards BC, Allen BC, Goldman CR

456 (2005) The effects of cultural eutrophication on the coupling between pelagic primary

457 producers and benthic consumers. Limnology and Oceanography 50:1368-1376

458 Cole JJ, Carpenter SR, Kitchell J, Pace ML, Solomon CT, Weidel B (2011) Strong

459 evidence for terrestrial support of zooplankton in small lakes based on stable isotopes of

460 carbon, nitrogen, and hydrogen. Proceedings of the National Academy of Sciences of

461 the United States of America 108:1975-1980

462 Cole JJ, Carpenter SR, Pace ML, Van de Bogert MC, Kitchell JL, Hodgson JR (2006) 
463 Differential support of lake food webs by three types of terrestrial organic carbon.

Dodson S. I. (2005) Introduction to Limnology $1^{\text {st }}$ ed, McGraw-Hill Companies Inc.

New York.

Doi H (2009) Spatial patterns of autochthonous and allochthonous resources in aquatic

France RL (1995) Carbon - 13 enrichment in benthic compared to planktonic algae -

Fry B (2006) Stable Isotope Ecology. Springer, New York

Fry B, Sherr EB (1984) $\quad \delta{ }^{13} \mathrm{C}$ measurements as indicators of carbon flow in marine and

Fujii S, Tanaka H, Somiya I (2002) Quantitative comparison of forests and other areas

with dry weather input loading in the Lake Biwa catchment area. Water Science and

Haga H, Ohtsuka T (2003) Changes in transparency (Secchi disk reading) of the pelagic zone of the main basin of Lake Biwa over a span of 73 years (in Japanese). Japanese

Haga H, Ohtsuka T, Matsuda M, Ashiya M (2007) Echosounding observations of 
481 coverage, height, PVI, and biomass of submerged macrophytes in the southern basin of 482 Lake Biwa, Japan. Limnology 8:95-102

483 Hama T, Nakamura K, Kawashima S (2010) Effectiveness of cyclic irrigation in 484 reducing suspended solids load from a paddy-field district. Agricultural Water 485 Management 97:483-489

486 Hothorn. T, Bretz. F, Westfall. P (2008) Simultaneous Inference in General Parametric 487 Models. Biometrical Journal 50:346-363

Karlsson J (2007) Different carbon support for respiration and secondary production in unproductive lakes. Oikos 116:1691-1696

Karlsson J, Sawstrom C (2009) Benthic algae support zooplankton growth during winter in a clear-water lake. Oikos 118:539-544 (2010) Carbon and nitrogen stable isotope ratios of macroinvertebrates in the littoral zone of Lake Biwa as indicators of anthropogenic activities in the watershed. Ecological

Kelly JR, Scheibling RE (2012) Fatty acids as dietary tracers in benthic food webs. 
499 Fujita N, Nagata T (2008) Use of Stable Nitrogen Isotope Signatures of Riparian

500 Macrophytes As an Indicator of Anthropogenic N Inputs to River Ecosystems.

501 Environmental Science \& Technology 42:7837-7841

502 Kohzu A, Tayasu I, Yoshimizu C, Maruyama A, Kohmatsu Y, Hyodo F, Onoda Y, Igeta

503 A, Matsui K, Nakano T, Wada E, Nagata T, Takemon Y (2009) Nitrogen-stable isotopic

504 signatures of basal food items, primary consumers and omnivores in rivers with

505 different levels of human impact. Ecological Research 24:127-136

506 Maki K, Kim C, Yoshimizu C, Tayasu I, Miyajima T, Nagata T (2010) Autochthonous

507 origin of semi-labile dissolved organic carbon in a large monomictic lake (Lake Biwa):

508 carbon stable isotopic evidence. Limnology 11:143-153

509 Marshall JD, Brooks JR, Lajtha K (2007) Sources of variation in the stable isotopic

510 composition of plants. In Michener R. and Lajtha K. (ed) Stable isotopes in Ecology and

511 Environmental Science, 2nd ed., Blackwell, Malden, pp 22-60

512 Tsuda R, Kumagai M, Kakui Y (1992) Spatial changes of phytoplanktonic size spectra

513 in Lake Biwa. Hydrobiologia 243-244:137-140

514 McClelland JW, Valiela I (1998) Linking nitrogen in estuarine producers to land-derived

515 sources. Limnology and Oceanography 43:577-585

516 Mortillaro JM, Abril G, Moreira-Turcq P, Sobrinho RL, Perez M, Meziane T (2011) 
517 Fatty acid and stable isotope (delta C-13, delta N-15) signatures of particulate organic

518 matter in the lower Amazon River: Seasonal contrasts and connectivity between

519 floodplain lakes and the mainstem. Organic Geochemistry 42:1159-1168

520 Murase J, Sakamoto M (2000) Horizontal distribution of carbon and nitrogen and their

521 isotopic compositions in the surface sediment of Lake Biwa. Limnology 1:177-184

522 Nakatsuji T, Nakamura K, Amano K (2006) Effects of wave and geomorphology on

523 growth and distribution of lakeshore vegetation (in Japanese). Journal of Japan Society

524 of Civil Engineers, Ser. G 62:135-140

525 Ohkubo T, Azuma Y (2005) Load of turbid from the watershed of Lake Biwa and its

526 effect on the lake water quality. Memorial volume of the Lake Biwa Research Institute

527 (in Japanese) Lake Biwa Research Institute, Otsu, Shiga, Japan:55-72

528 Okuda N, Takeyama T, Komiya T, Kato Y, Okuzaki Y, Karube Z, Sakai Y, Hori M,

Tayasu I, Nagata T (2012) A food web and its long-term dynamics in Lake Biwa: a

530

stable isotope approach. In: KawanabeH. et al. (ed) Lake Biwa: Interactions between

nature and people. Springer Academic, Amsterdam, pp205-210

Pace ML, Carpenter SR, Cole JJ, Coloso JJ, Kitchell JF, Hodgson JR, Middelburg JJ, 
Phillips DL, Gregg JW (2003) Source partitioning using stable isotopes: coping with too many sources. Oecologia 136:261-269

Linear and Nonlinear Mixed Effects Models. R package version 3.1-102. zooplankton in shallow subarctic and arctic waters. Ecography 30:77-87

543 Computing. R Foundation for Statistical Computing, Vienna, Austria.

544 Rossiter A (2000) Lake Biwa as a topical ancient lake In: Rossiter A, Kawanabe H (ed)

545 Ancient Lakes: Biodiversity, Ecology and Evolution. Advances in Ecological Research

546 31: 571-598, Academic Press, London

547 Sakamoto M (2000) Organisms in Lake Biwa. In: Somiya I (ed) Lake Biwa:

548 environment and water quality formation (in Japanese), Gihodoshuppan, Tokyo, pp $187-246$

Shiga prefecture (1992-2002) White paper on the environment of Shiga Prefecture (in

Somiya I (ed) (2000) Lake Biwa: environment and water quality formation (in 
Japanese). Gihodoshuppan, Tokyo

Tabei A (2001) Perfect master of SPSS: Questionnaire data analysis using covariance structure analysis (AMOS) (in Japanese). Tokyotosyoshuppan, Tokyo reference materials for carbon- and nitrogen-stable isotope ratio measurements provided by Center for Ecological Research, Kyoto University, and Institute of Biogeosciences, Japan Agency for Marine-Earth Science and Technology. Limnology 1-6 in Lake Biwa. Hydrobiologia 243-244:137-140

Vadeboncoeur Y, Jeppesen E, Vander Zanden MJ, Schierup HH, Christoffersen K, Lodge DM (2003) From Greenland to green lakes: Cultural eutrophication and the loss of benthic pathways in lakes. Limnology and Oceanography 48:1408-1418 distribution of primary production between benthic and pelagic habitats. Ecology

Vander Zanden MJ, Vadeboncoeur Y, Chandra S (2011) Fish Reliance on littoral-benthic resources and the distribution of primary production in lakes. Ecosystems 14:894-903 
571 Yamamura K (1999) Transformation using $(x+0.5)$ to stabilize the variance of

572 populations. Research on Population Ecology 41:229-234

573

574 


\section{$576 \quad$ Figure and Table Legends}

$577 \quad$ Fig. 1

578 A map of POC sampling sites (no. 1-30) in the near-shore waters of Lake Biwa.

579 No. 30 is the reference site for P-POM. See Appendix A and B for details of site

580 information.

581

$582 \quad$ Fig. 2

583 Carbon and nitrogen isotopic signatures of near-shore POM and their potential organic

584 sources (P-POM, E-POM and R-POM). Each plot represents mean from all sampling

585 sites, and vertical and horizontal bars indicate range (also see Appendix C). Note that

P-POM data are derived from only a pelagic site.

587

588

Fig. 3

589 An a priori path model to explain the variation in T-POC concentrations in the

590 near-shore waters of Lake Biwa. The model consists of two components. Unidirectional

591 arrows indicate a causal effect and double headed arrows interactive effect.

592

$593 \quad$ Fig. 4 
594 Spatiotemporal variations in the concentrations of three components, P-POC, E-POC

595 and T-POC, of POC in the near-shore waters of Lake Biwa. The size of each circle is

596 proportional to the POC concentration. Transparent circles represent sites where the

597 relative contributions of three potential organic sources could not be estimated (see

598 Materials and Methods).

599

$600 \quad$ Fig. 5

601 Seasonal changes in the composition of three potential organic sources of POC in the

602 near-shore waters of Lake Biwa. Vertical bars are the standard deviation.

603

$604 \quad$ Fig. 6

605 The path model based on the simultaneous analysis of multiple populations with

606 structured means. The basic framework is the same as that in Figure 2. Dark and light

607 arrows are significant $(\mathrm{p}<0.05)$ and not significant $(\mathrm{p}>0.05)$ paths, respectively.

608 Values with arrows are path coefficients. The subscripts of R-POC and log (T-POC)

609 indicate the total effect on these variables.

610 
612 Table 1

613 Measured POC concentration and estimated P-POC, E-POC and T-POC concentrations

$614\left(\mathrm{mgL}^{-1}\right)$ at each coastal site in Lake Biwa.

615

616 


\section{Appendix A}

619 Geographic information system (GIS) data and riverine organic matter for each tributary

620 catchment area. Land use pattern is expressed as the proportional area.

621

622 Appendix B

623 The major environmental data and the physical characteristics of the corresponding

624 coastal site.

625

626 Appendix C

627 Carbon and nitrogen stable isotope ratios (\%) of POM and its three potential sources

628 (P-POM, E-POM, and R-POM) at each coastal site.

629

630 Appendix D

631 The relative contribution (\%) of the three potential sources (P-POM, E-POM and

632 T-POM) to POM at each coastal site.

633 


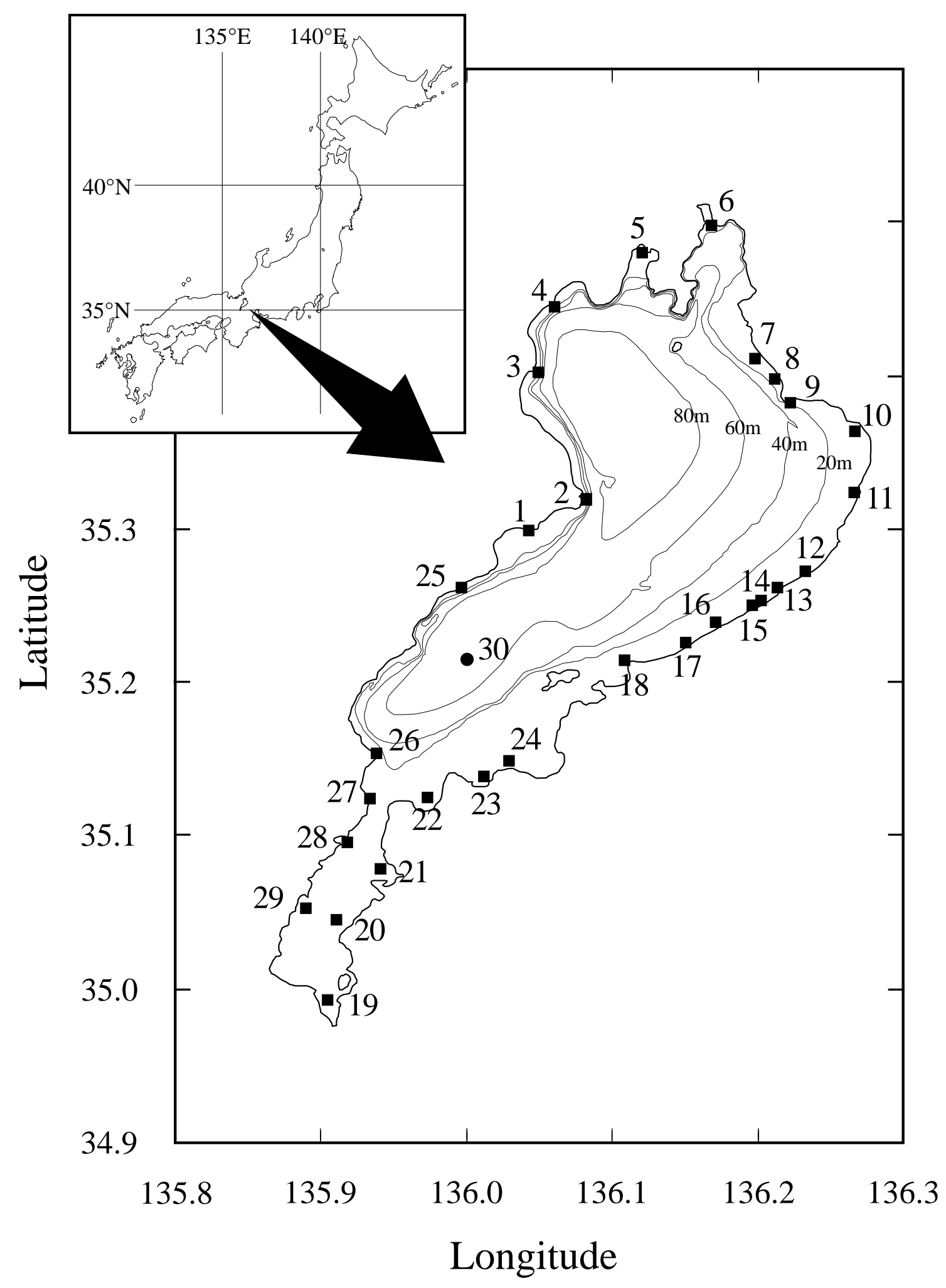

Fig. 1 


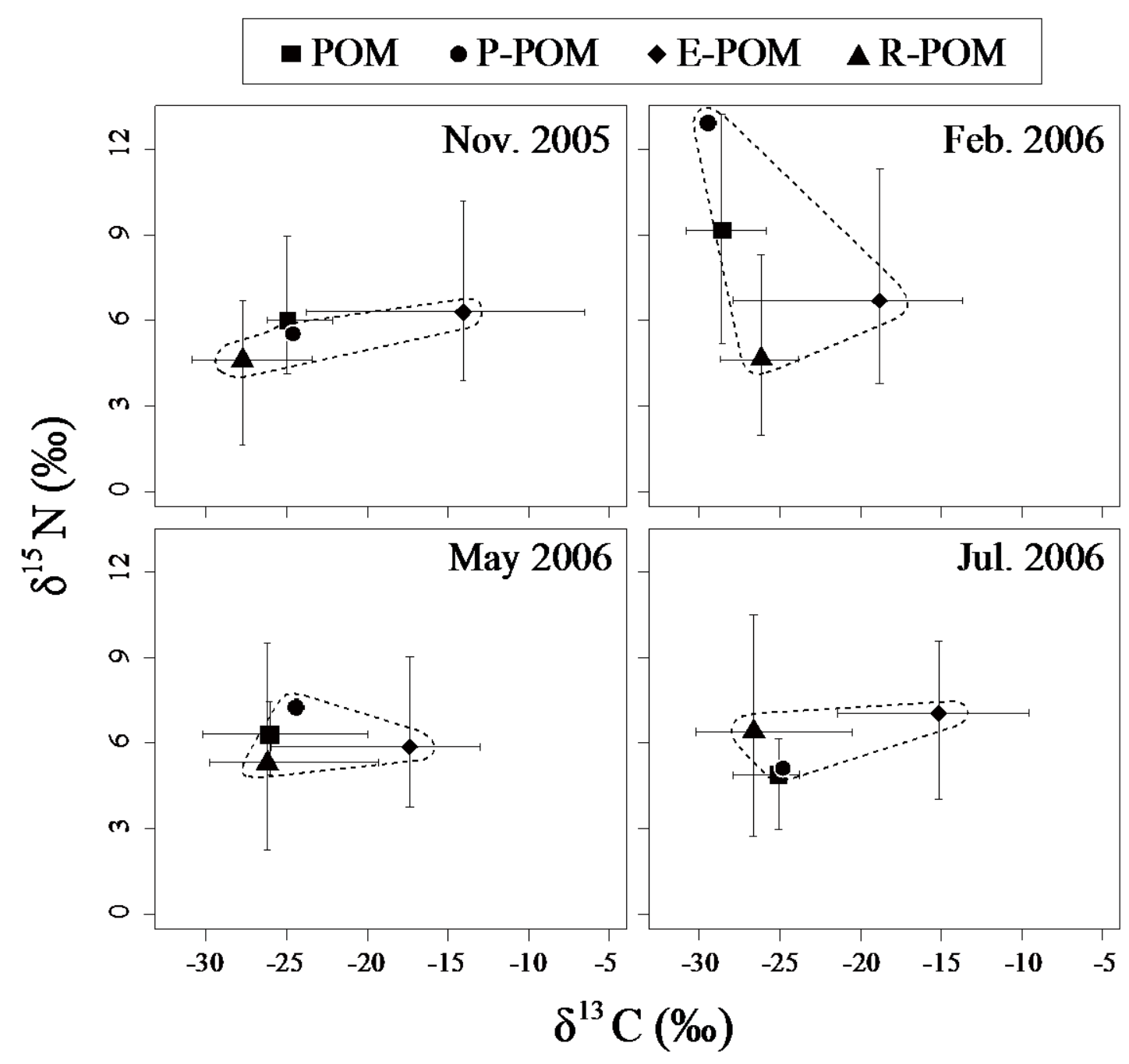

Fig. 2 


\section{Component 1 \\ Path 3}
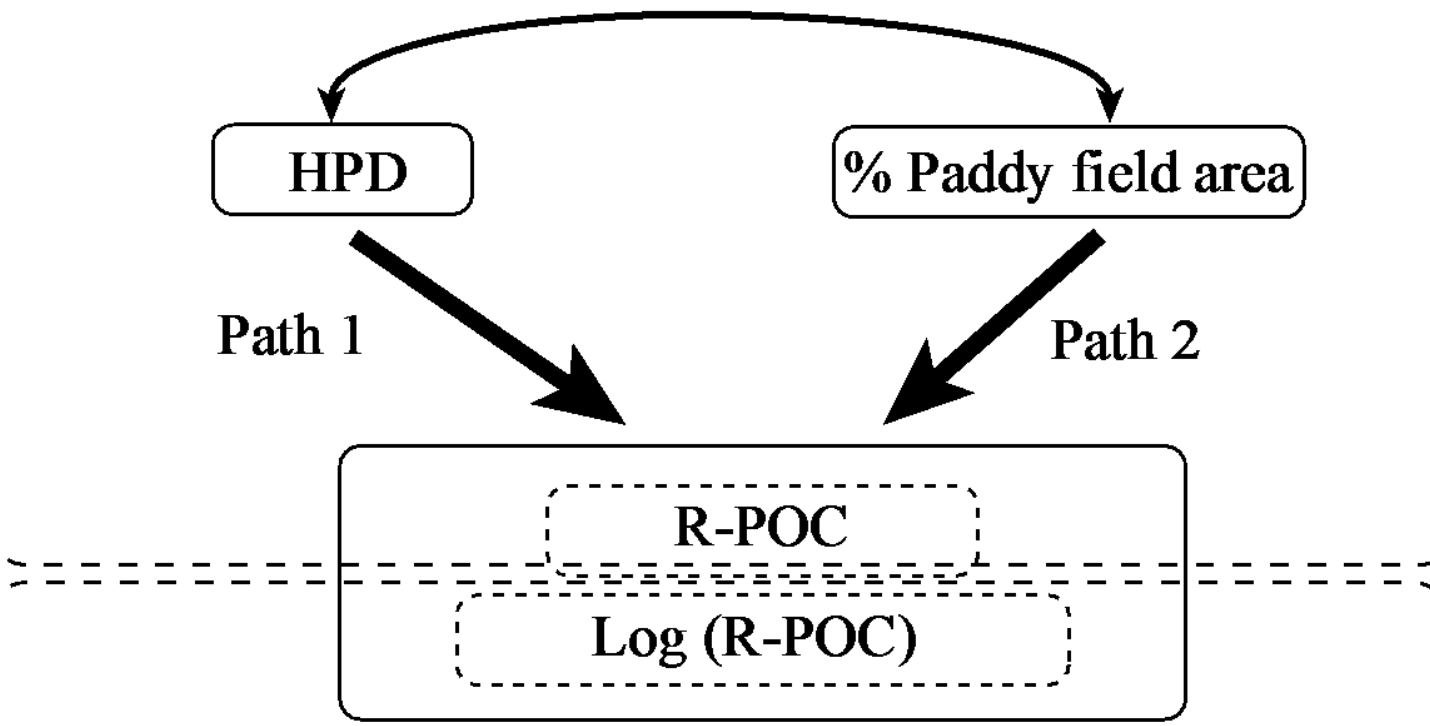

Log (River discharge)
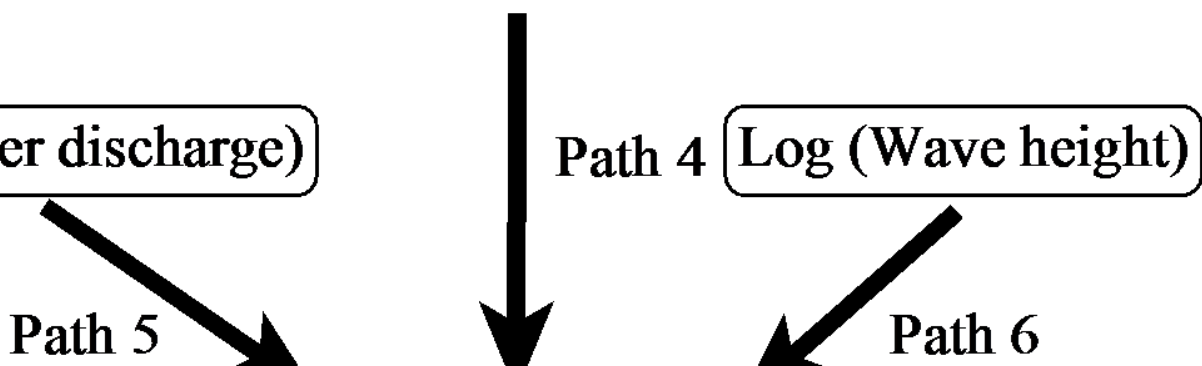

Component 2

$$
\text { Log (Coastal slope) }
$$

Fig. 3 


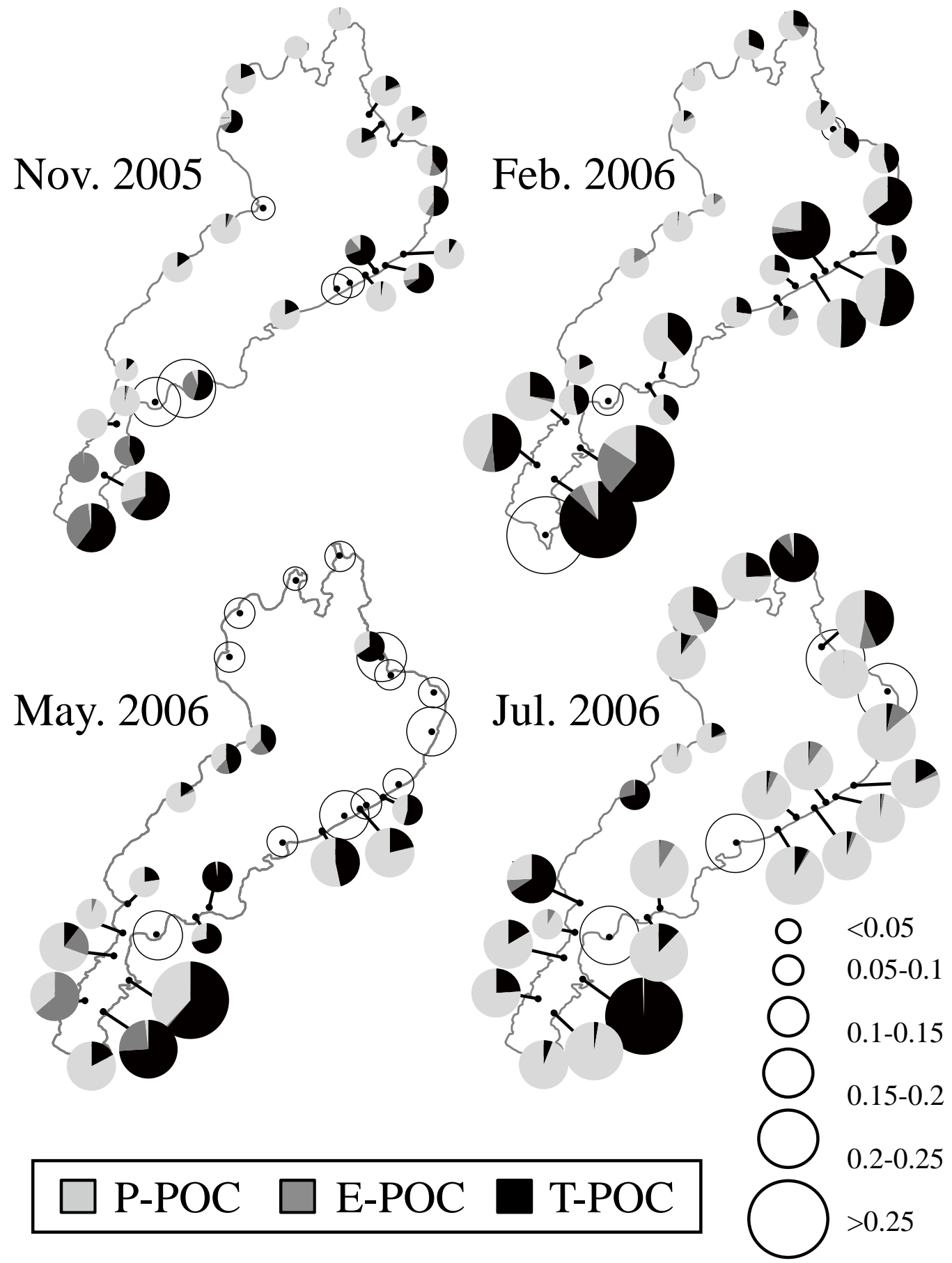

$\log (\mathrm{x}+0.5) \mathrm{mg} \mathrm{L}^{-1}$

Fig. 4 


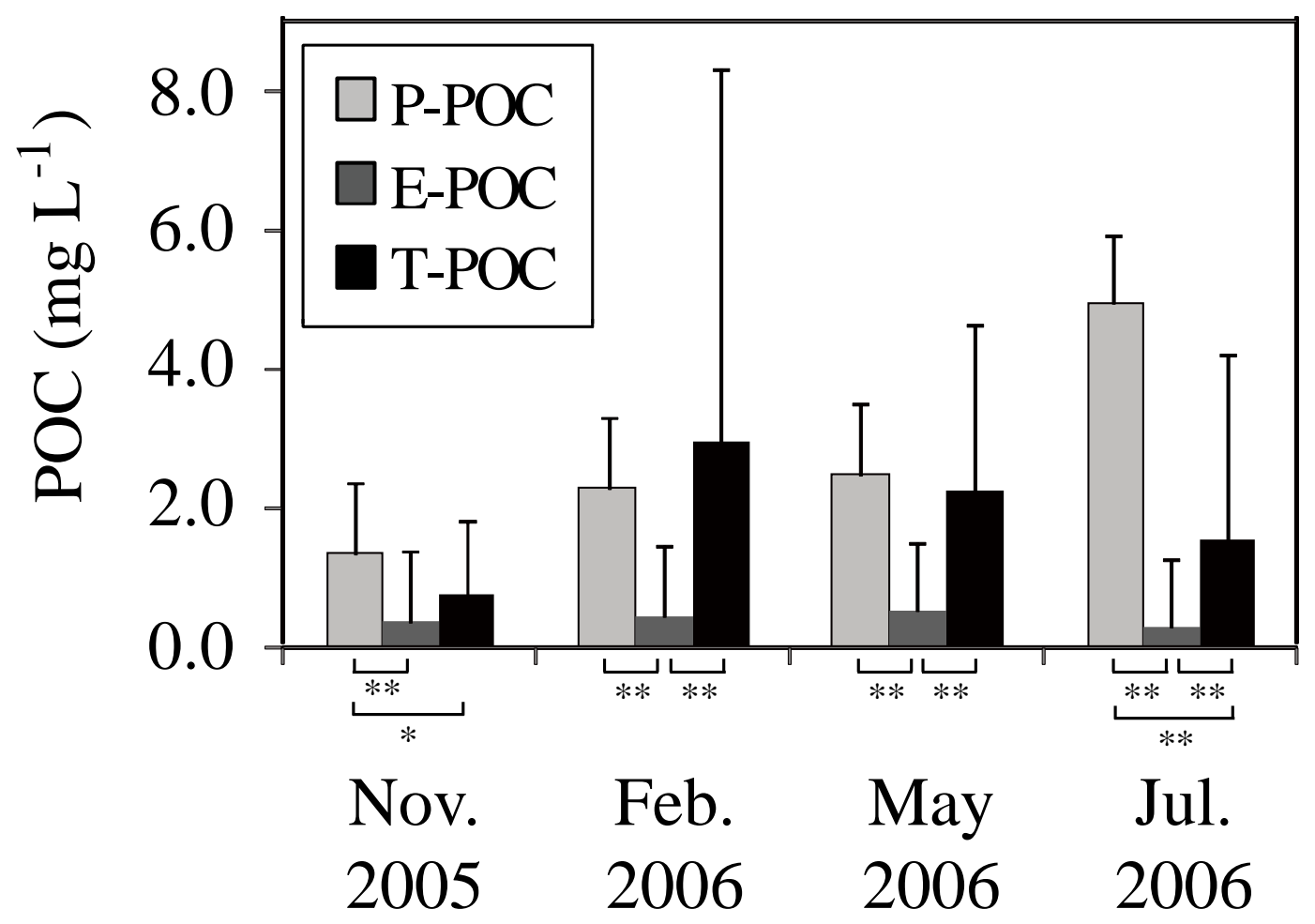

Fig. 5 
Nov. 2005
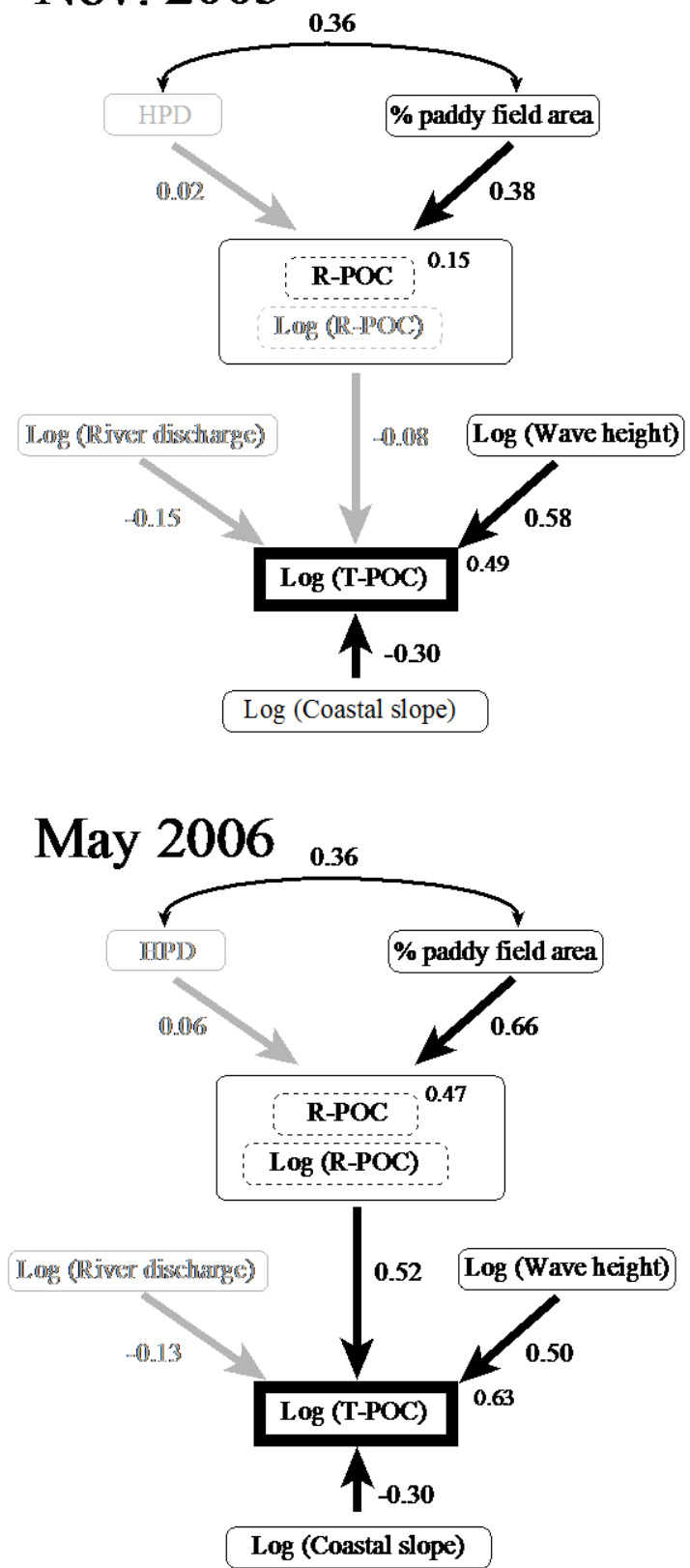

Feb. 2006
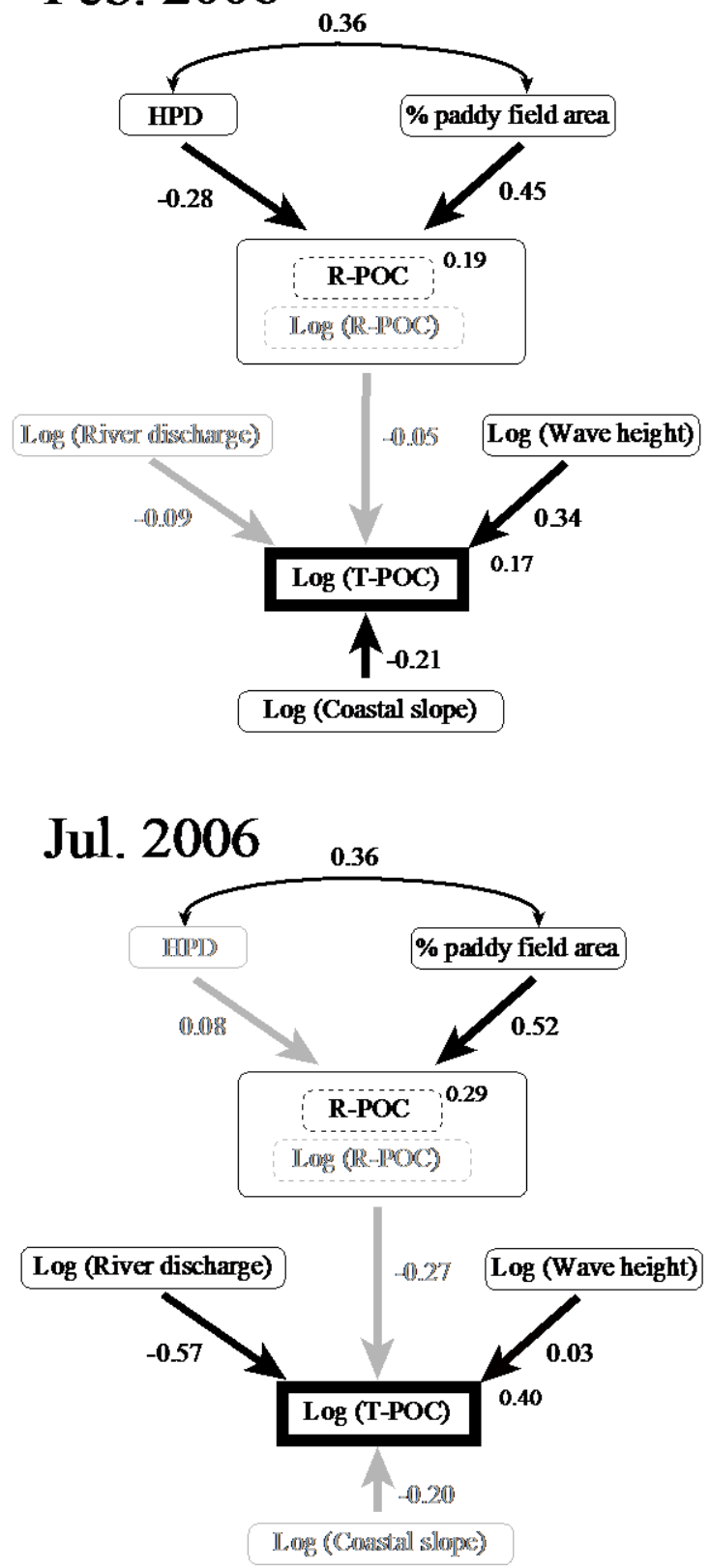

Fg. 6 
Table 1

Measured POC concentration and estimated P-POC, E-POC and T-POC concentrations (mg L-1) at each coastal site in Lake Biwa.

\begin{tabular}{|c|c|c|c|c|c|c|c|c|c|c|c|c|c|c|c|c|c|}
\hline \multirow{2}{*}{ Site no. } & \multirow{2}{*}{$\begin{array}{c}\text { Name of } \\
\text { tributary rivers }\end{array}$} & \multicolumn{4}{|c|}{ Nov. 2005} & \multicolumn{4}{|c|}{ Feb. 2006} & \multicolumn{4}{|c|}{ May 2006} & \multicolumn{4}{|c|}{ Jul. 2006} \\
\hline & & POC & P-POC & E-POC & T-POC & POC & P-POC & E-POC & T-POC & POC & P-POC & E-POC & T-POC & POC & P-POC & E-POC & T-POC \\
\hline 1 & Kamo River & 1.614 & 1.473 & 0.077 & 0.061 & 3.346 & 3.286 & 0.013 & 0.047 & 3.897 & 1.489 & 0.596 & 1.812 & 3.421 & 3.281 & 0.109 & 0.031 \\
\hline 2 & Ado R. & 1.493 & & & & 1.226 & 1.060 & 0.147 & 0.020 & 1.724 & 0.655 & 0.360 & 0.708 & 4.256 & 3.349 & 0.145 & 0.757 \\
\hline 3 & Ishida R. & 1.446 & 0.450 & 0.139 & 0.857 & 0.981 & 0.801 & 0.061 & 0.120 & 1.796 & & & & 6.145 & 5.408 & 0.277 & 0.461 \\
\hline 4 & Momose R. & 2.300 & 1.851 & 0.007 & 0.442 & 1.242 & 1.226 & 0.009 & 0.009 & 2.531 & & & & 5.720 & 3.318 & 0.686 & 1.722 \\
\hline 5 & Oura R. & 1.222 & 1.213 & 0.004 & 0.004 & 2.274 & 1.569 & 0.000 & 0.705 & 0.921 & & & & 7.029 & 5.286 & 0.056 & 1.687 \\
\hline 6 & Shiotsu-o R. & 1.249 & 1.225 & 0.014 & 0.009 & 2.310 & 1.400 & 0.284 & 0.626 & 4.259 & & & & 5.567 & 0.167 & 0.484 & 4.916 \\
\hline 7 & Chonoki R. & 1.709 & 1.355 & 0.048 & 0.306 & 1.771 & 1.593 & 0.000 & 0.177 & 4.395 & 1.481 & 0.040 & 2.875 & 8.603 & 4.069 & 0.792 & 3.742 \\
\hline 8 & Ta R. & 1.713 & 1.358 & 0.048 & 0.307 & 1.391 & & & & 4.586 & 0.000 & 0.000 & 0.000 & 7.001 & & & \\
\hline 9 & Ane R. & 1.963 & 1.580 & 0.075 & 0.308 & 1.862 & 1.178 & 0.013 & 0.670 & 2.595 & & & & 6.974 & 6.939 & 0.035 & 0.000 \\
\hline 10 & Yone R. & 1.607 & 0.754 & 0.212 & 0.640 & 2.953 & 1.603 & 0.009 & 1.343 & 3.291 & 0.000 & 0.000 & 0.000 & 10.145 & & & \\
\hline 11 & Amano R. & 1.711 & 0.707 & 0.147 & 0.857 & 6.035 & 2.124 & 0.024 & 3.886 & 4.758 & & & & 8.501 & 7.337 & 0.867 & 0.298 \\
\hline 12 & Seri R. & 2.166 & 1.967 & 0.022 & 0.178 & 4.101 & 2.215 & 0.021 & 1.866 & 3.021 & 0.000 & 0.000 & 0.000 & 6.820 & 5.524 & 0.184 & 1.112 \\
\hline 13 & Inukami R. & 1.866 & 0.507 & 0.140 & 1.216 & 8.151 & 3.831 & 0.000 & 4.320 & 4.348 & 1.991 & 0.009 & 2.348 & 6.617 & 6.432 & 0.119 & 0.066 \\
\hline 14 & Ajiki R. & 2.116 & 0.224 & 0.421 & 1.473 & 9.595 & 2.178 & 0.384 & 7.024 & 3.378 & 0.000 & 0.000 & 0.000 & 6.102 & 5.504 & 0.531 & 0.073 \\
\hline 15 & Uso R. & 4.483 & 4.339 & 0.031 & 0.112 & 6.672 & 3.303 & 0.000 & 3.369 & 4.984 & 3.908 & 0.030 & 1.052 & 6.047 & 5.654 & 0.181 & 0.212 \\
\hline 16 & Bunroku R. & 2.601 & & & & 2.533 & 1.824 & 0.000 & 0.709 & 4.699 & 0.000 & 0.000 & 0.000 & 5.470 & 5.054 & 0.284 & 0.137 \\
\hline 17 & Nomazu R. & 2.794 & & & & 3.336 & 2.605 & 0.400 & 0.327 & 6.483 & 3.468 & 0.000 & 3.015 & 9.929 & 9.055 & 0.109 & 0.764 \\
\hline 18 & Echi R. & 3.920 & 3.175 & 0.008 & 0.737 & 2.327 & 1.682 & 0.016 & 0.628 & 3.701 & & & & 12.012 & & & \\
\hline 20 & Hayama R. & 6.262 & 1.828 & 0.645 & 3.782 & 21.669 & 1.517 & 1.408 & 18.744 & 8.838 & 0.168 & 2.121 & 6.549 & 9.259 & 9.027 & 0.000 & 0.231 \\
\hline 21 & Shin-moriyama R. & 3.095 & 0.025 & 1.711 & 1.362 & 34.982 & 5.527 & 8.046 & 21.409 & 14.337 & 5.448 & 0.115 & 8.774 & 12.896 & 0.064 & 0.000 & 12.831 \\
\hline 22 & Yasu R. & 6.179 & & & & 3.684 & & & & 6.571 & & & & 11.995 & & & \\
\hline 23 & Yanomune R. & 11.544 & & & & 3.388 & 2.101 & 0.000 & 1.287 & 3.883 & 1.091 & 0.043 & 2.753 & 11.108 & 9.742 & 0.022 & 1.344 \\
\hline 24 & Hino R. & 3.567 & 0.235 & 1.384 & 1.948 & 5.953 & 3.661 & 0.000 & 2.292 & 3.339 & 0.053 & 0.013 & 3.273 & 9.522 & 8.665 & 0.809 & 0.048 \\
\hline 25 & U R. & 2.136 & 1.816 & 0.000 & 0.320 & 2.263 & 1.878 & 0.373 & 0.011 & 3.161 & 2.580 & 0.095 & 0.487 & 3.545 & 0.025 & 0.982 & 2.542 \\
\hline 26 & Wani R. & 1.117 & 0.978 & 0.003 & 0.136 & 3.539 & 2.902 & 0.000 & 0.637 & 2.741 & 2.119 & 0.005 & 0.617 & 4.516 & 1.165 & 0.379 & 2.972 \\
\hline 27 & Mano R. & 2.322 & 2.220 & 0.063 & 0.039 & 2.585 & 1.383 & 0.000 & 1.202 & 4.185 & 3.955 & 0.230 & 0.000 & 3.694 & 3.380 & 0.314 & 0.000 \\
\hline 28 & Tenjin R. & 3.431 & 3.431 & 0.000 & 0.000 & 5.342 & 3.776 & 0.118 & 1.448 & 4.860 & 3.377 & 0.967 & 0.510 & 5.831 & 4.869 & 0.000 & 0.962 \\
\hline 29 & Fujinoki R. & 2.081 & 0.010 & 2.071 & 0.000 & 8.922 & 3.953 & 0.625 & 4.345 & 6.095 & 2.206 & 3.870 & 0.018 & 6.197 & 4.709 & 0.000 & 1.487 \\
\hline \multicolumn{18}{|c|}{ Offshore reference site } \\
\hline 30 & Ie-1 & 2.38 & & & & 2.22 & & & & 3.01 & & & & 4.73 & & & \\
\hline
\end{tabular}




\section{Appendix A}

Geographic information system (GIS) data and riverine organic matter for each tributary catchment area. Land use pattern is expressed as the proportional area.

\begin{tabular}{|c|c|c|c|c|c|c|c|c|c|c|c|c|c|c|c|c|c|c|c|}
\hline \multirow[t]{2}{*}{ Station Name } & \multirow[t]{2}{*}{$\begin{array}{l}\text { Human } \\
\text { population } \\
\text { (ind) }\end{array}$} & \multirow[t]{2}{*}{$\begin{array}{l}\text { Human } \\
\text { population } \\
\text { density } \\
\text { (ind. } \mathrm{km}^{-2} \text { ) }\end{array}$} & \multirow[t]{2}{*}{$\begin{array}{l}\text { Catchment } \\
\text { area } \\
\left(\mathrm{km}^{-2}\right)\end{array}$} & \multirow[t]{2}{*}{$\begin{array}{l}\text { \% Paddy } \\
\text { field }\end{array}$} & \multirow[t]{2}{*}{$\begin{array}{l}\% \text { Other } \\
\text { crop land } \\
\text { area }\end{array}$} & \multirow[t]{2}{*}{$\begin{array}{c}\% \text { Forest } \\
\text { area }\end{array}$} & \multirow[t]{2}{*}{$\begin{array}{l}\% \text { Waste } \\
\text { land area }\end{array}$} & \multirow[t]{2}{*}{$\begin{array}{c}\% \\
\text { Residential } \\
\text { area }\end{array}$} & \multirow[t]{2}{*}{$\begin{array}{c}\% \text { Traffic } \\
\text { area }\end{array}$} & \multirow[t]{2}{*}{$\begin{array}{l}\text { \% Liver } \\
\text { and Lake } \\
\text { area }\end{array}$} & \multirow[t]{2}{*}{$\begin{array}{c}\% \text { Other } \\
\text { area }\end{array}$} & \multicolumn{4}{|c|}{$\begin{array}{c}\text { Riverin Particulate Organic Nutrient (PON) } \\
\left(\mu \mathrm{mol} \mathrm{L}^{-1}\right)\end{array}$} & \multicolumn{4}{|c|}{$\begin{array}{l}\text { Riverin Particulate Organic Carbon (POC) } \\
\qquad\left(\mu \mathrm{mol} \mathrm{L}^{-1}\right)\end{array}$} \\
\hline & & & & & & & & & & & & Nov. 2005 & Feb. 2006 & May 2006 & Jul. 2006 & Nov. 2005 & Feb. 2006 & May 2006 & Jul. 2006 \\
\hline 1 Kamo River & 4149 & 89.16 & 46.531 & 18.13 & 0.48 & 74.80 & 1.67 & 1.20 & 0.09 & 2.05 & 1.58 & 1.014 & 2.779 & 2.722 & 2.331 & 9.872 & 29.989 & 22.935 & 20.056 \\
\hline 2 Ado R. & 8185 & 26.74 & 306.123 & 3.11 & 0.54 & 91.45 & 1.42 & 0.71 & 0.01 & 1.76 & 0.80 & 0.979 & 0.331 & 1.842 & 1.280 & 7.518 & 2.459 & 11.818 & 10.687 \\
\hline 3 Ishida R. & 5023 & 83.83 & 59.926 & 9.58 & 0.93 & 81.11 & 4.13 & 1.96 & 0.02 & 0.86 & 1.42 & 0.666 & 0.696 & 2.450 & 1.190 & 5.820 & 7.297 & 16.998 & 11.342 \\
\hline 4 Momose $\mathrm{R}$. & 851 & 64.74 & 13.142 & 4.02 & 0.34 & 87.69 & 1.23 & 0.56 & 0.00 & 3.07 & 3.10 & 0.731 & 0.818 & 3.508 & 2.757 & 5.797 & 7.669 & 31.119 & 27.666 \\
\hline 5 Oura R. & 3828 & 97.62 & 39.209 & 11.28 & 1.61 & 78.52 & 2.19 & 2.67 & 0.16 & 0.94 & 2.63 & 7.627 & 9.810 & 4.809 & 4.032 & 96.905 & 136.730 & 45.918 & 46.646 \\
\hline 6 Shiotsu-o R. & 1111 & 55.03 & 20.242 & 6.66 & 0.38 & 86.85 & 1.29 & 1.57 & 1.34 & 1.38 & 0.51 & 11.435 & 9.279 & 2.485 & 1.822 & 143.682 & 148.315 & 21.167 & 19.257 \\
\hline 7 Chonoki R. & 4219 & 412.28 & 10.234 & 76.29 & 3.61 & 0.09 & 0.08 & 13.52 & 0.01 & 5.13 & 1.27 & 5.815 & 31.818 & 9.420 & 2.305 & 51.361 & 264.691 & 69.923 & 21.837 \\
\hline 8 Ta R. & 10853 & 301.33 & 36.016 & 46.68 & 2.08 & 37.10 & 0.25 & 9.59 & 1.39 & 1.93 & 0.99 & 11.907 & 12.720 & 5.298 & 9.858 & 118.184 & 133.328 & 44.291 & 120.706 \\
\hline 9 Ane R. & 22516 & 60.57 & 372.261 & 5.91 & 1.08 & 88.16 & 0.81 & 1.70 & 0.06 & 1.63 & 0.65 & 2.926 & 6.996 & 1.618 & 1.064 & 28.161 & 90.280 & 12.117 & 10.066 \\
\hline 10 Yone R. & 31047 & 2047.40 & 15.164 & 54.84 & 1.27 & 0.76 & 0.00 & 34.54 & 1.82 & 1.50 & 5.27 & 2.825 & 2.312 & 1.858 & 3.281 & 23.010 & 25.849 & 17.330 & 34.578 \\
\hline 11 Amano R. & 24994 & 225.70 & 110.935 & 18.48 & 2.48 & 66.31 & 1.49 & 5.82 & 1.44 & 1.97 & 2.01 & 21.215 & 1.770 & 2.883 & 1.538 & 160.075 & 18.646 & 24.513 & 14.668 \\
\hline 12 Seri R. & 34039 & 462.06 & 73.859 & 6.96 & 0.91 & 75.20 & 2.20 & 8.09 & 1.32 & 2.36 & 2.60 & 5.529 & 1.807 & 1.467 & 2.036 & 37.959 & 20.657 & 11.392 & 17.104 \\
\hline 13 Inukami R. & 11066 & 109.47 & 101.626 & 6.74 & 0.86 & 82.16 & 3.30 & 2.79 & 0.41 & 3.14 & 0.59 & 7.760 & 2.186 & 0.820 & 0.802 & 45.100 & 24.647 & 7.002 & 7.234 \\
\hline 14 Ajiki R. & 14870 & 1001.57 & 14.847 & 70.24 & 0.68 & 1.06 & 0.14 & 20.11 & 1.25 & 1.80 & 4.72 & 24.544 & 4.425 & 5.132 & 4.172 & 185.768 & 40.110 & 36.507 & 47.858 \\
\hline 15 Uso R. & 34452 & 411.42 & 83.740 & 51.72 & 0.97 & 28.60 & 1.22 & 11.05 & 1.58 & 2.41 & 2.45 & 39.132 & 7.403 & 3.870 & 3.420 & 312.742 & 81.385 & 30.546 & 27.136 \\
\hline 16 Bunroku R. & 8323 & 595.25 & 13.981 & 66.79 & 1.22 & 15.68 & 0.90 & 11.69 & 0.00 & 2.35 & 1.35 & 21.247 & 4.018 & 6.447 & 5.407 & 170.537 & 39.113 & 55.116 & 60.821 \\
\hline 17 Nomazu R. & 5465 & 757.58 & 7.214 & 65.99 & 0.71 & 3.58 & 0.00 & 20.17 & 1.13 & 2.21 & 6.22 & 14.473 & 2.336 & 4.710 & 4.045 & 119.538 & 24.225 & 38.565 & 36.029 \\
\hline 18 Echi R. & 22957 & 109.59 & 211.139 & 10.41 & 0.72 & 77.97 & 2.85 & 2.54 & 0.10 & 4.79 & 0.61 & 8.799 & 0.936 & 2.579 & 0.997 & 64.881 & 7.945 & 22.102 & 9.721 \\
\hline 19 Nagaso R. & 11728 & 3174.29 & 3.695 & 18.35 & 2.40 & 20.63 & 1.09 & 31.40 & 7.95 & 5.86 & 12.32 & 17.375 & 4.968 & 4.116 & 1.917 & 138.208 & 53.009 & 34.308 & 46.767 \\
\hline 20 Hayama R. & 68910 & 2047.95 & 33.648 & 43.70 & 0.59 & 7.52 & 1.19 & 29.70 & 3.18 & 3.53 & 8.75 & 14.215 & 2.556 & 9.411 & 2.274 & 120.184 & 27.370 & 69.935 & 22.470 \\
\hline 21 Shin-moriyama R. & 14426 & 2539.60 & 5.680 & 54.53 & 0.19 & 1.16 & 0.37 & 33.73 & 0.10 & 0.59 & 9.34 & 16.716 & 4.585 & 7.420 & 3.444 & 134.247 & 36.162 & 62.000 & 29.964 \\
\hline 22 Yasu R. & 126122 & 324.12 & 391.183 & 19.96 & 2.51 & 57.67 & 2.16 & 6.50 & 0.40 & 5.58 & 3.11 & 12.572 & 2.348 & 3.311 & 2.595 & 92.455 & 19.354 & 23.234 & 20.113 \\
\hline 23 Yanomune $\mathrm{R}$. & 35935 & 858.81 & 41.842 & 52.27 & 1.38 & 19.47 & 2.18 & 15.72 & 0.99 & 3.91 & 4.07 & 22.867 & 3.154 & 7.158 & 4.218 & 179.294 & 27.223 & 61.422 & 43.261 \\
\hline 24 Hino R. & 76360 & 338.11 & 225.846 & 31.26 & 2.14 & 44.32 & 2.02 & 8.42 & 0.43 & 4.89 & 4.41 & 13.271 & 3.116 & 6.309 & 3.253 & 82.902 & 25.800 & 45.762 & 29.626 \\
\hline 25 U R. & 465 & 66.15 & 7.028 & 5.96 & 0.00 & 89.06 & 0.45 & 0.81 & 0.32 & 0.78 & 2.62 & 12.367 & 0.278 & 1.063 & 0.917 & 158.484 & 2.551 & 10.894 & 12.313 \\
\hline 26 Wani R. & 3203 & 186.48 & 17.174 & 15.96 & 0.12 & 65.86 & 4.66 & 5.42 & 1.89 & 0.93 & 2.67 & 8.895 & 3.876 & 2.124 & 1.292 & 75.623 & 29.538 & 16.125 & 11.239 \\
\hline 27 Mano R. & 24305 & 1048.33 & 23.184 & 28.45 & 0.33 & 42.77 & 6.63 & 15.60 & 1.96 & 1.13 & 2.99 & 9.137 & 2.074 & 3.458 & 2.101 & 69.424 & 22.013 & 24.245 & 16.789 \\
\hline 28 Tenjin R. & 5268 & 539.33 & 9.768 & 27.48 & 0.95 & 54.70 & 4.15 & 7.31 & 2.79 & 0.86 & 1.76 & 11.925 & 1.573 & 5.300 & 2.673 & 87.948 & 14.400 & 34.817 & 28.289 \\
\hline 29 Fujinoki R. & 7116 & 1804.68 & 3.943 & 16.19 & 0.53 & 49.08 & 0.28 & 20.76 & 3.49 & 0.27 & 9.39 & 16.805 & 1.161 & 0.896 & 1.596 & 169.476 & 10.000 & 6.440 & 21.301 \\
\hline
\end{tabular}




\section{Appendix B}

The major environmental data and the physical characteristics of the corresponding coastal site.

\begin{tabular}{|c|c|c|c|c|c|c|c|c|c|c|c|c|c|c|c|c|c|c|c|c|c|}
\hline \multirow[t]{2}{*}{ Site no. } & \multirow[t]{2}{*}{$\begin{array}{c}\text { Name of } \\
\text { tributary rivers }\end{array}$} & \multicolumn{2}{|c|}{ Sampling location } & \multirow{2}{*}{$\begin{array}{l}\text { Wave } \\
\text { hight } \\
\text { (m) }\end{array}$} & \multirow{2}{*}{$\begin{array}{c}\text { Wave } \\
\text { energyflux } \\
\left(\mathrm{kg} \mathrm{m} \text { day }^{-1} \mathrm{~m}^{-1}\right)\end{array}$} & \multirow{2}{*}{$\begin{array}{l}\text { Lake shore } \\
\text { energy flux } \\
\left(\mathrm{kg} \mathrm{m} \text { day }^{-1} \mathrm{~m}^{-1}\right)\end{array}$} & \multirow{2}{*}{$\begin{array}{c}\text { Coastal } \\
\text { slope } \\
\text { (1 distance }\end{array}$} & \multirow{2}{*}{$\begin{array}{l}\text { Sand } \\
\text { beach } \\
\text { width } \\
\text { (m) }\end{array}$} & \multirow{2}{*}{$\begin{array}{l}\text { Reed } \\
\text { grassfield } \\
\text { width } \\
\text { (m) }\end{array}$} & \multirow{2}{*}{\multicolumn{3}{|c|}{$\begin{array}{c}\text { Chl.a of near-shore POM } \\
\left(\mu \mathrm{gl} \mathrm{L} \mathrm{L}^{-1}\right)\end{array}$}} & \multicolumn{5}{|c|}{ Conductivity } & \multicolumn{4}{|c|}{$\mathrm{pH}$} \\
\hline & & Latitude & Longitude & & & & & & & & & & Jul. 2006 & Nov. 2005 & $\begin{array}{r}(\mathrm{mS} \\
\text { Feb. } 2006 \\
\end{array}$ & & & Nov. 2005 & Feb. 2006 & May 2006 & Jul. 2006 \\
\hline 1 & Kamo River & $35^{\circ} 17.921^{\prime}$ & $136^{\circ} 02.645^{\prime}$ & 0.08 & -93.08 & 15.82 & 10.72 & 19 & 0 & 2.145 & 1.168 & 1.565 & 1.872 & 14 & 14 & 13 & 13 & 8.040 & 7.340 & 7.900 & 7.170 \\
\hline 2 & Ado R. & $35^{\circ} 19.186^{\prime}$ & $136^{\circ} 04.947^{\prime}$ & 0.09 & 15.07 & 14.42 & 8.12 & 8 & 0 & 1.333 & 0.752 & 1.275 & 1.872 & 13 & 13 & 13 & 13 & 7.440 & 7.360 & 6.800 & 7.620 \\
\hline 3 & Ishida R. & $35^{\circ} 24.185^{\prime}$ & $136^{\circ} 03.058^{\prime}$ & 0.08 & 183.11 & 33.68 & 9.37 & 20 & 0 & 1.971 & 0.752 & 1.275 & 3.188 & 13 & 14 & 13 & 13 & 7.310 & 7.660 & 7.500 & 7.830 \\
\hline 4 & Momose $\mathrm{R}$. & $35^{\circ} 26.660^{\prime}$ & $136^{\circ} 03.776^{\prime}$ & 0.08 & 109.58 & 11.76 & 7.00 & 18 & 0 & 1.739 & 0.869 & 2.027 & 3.237 & 13 & 21 & 12 & 13 & 8.050 & 7.650 & 6.500 & 7.600 \\
\hline 5 & Oura R. & $35^{\circ} 28.851^{\prime}$ & $136^{\circ} 07.307^{\prime}$ & - & - & - & 8.61 & - & 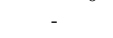 & 1.913 & 0.788 & 1.722 & 4.943 & 13 & 14 & 13 & 12 & 8.090 & 7.560 & 8.800 & 8.010 \\
\hline 6 & Shiotsu-o R. & $35^{\circ} 30.046^{\prime}$ & $136^{\circ} 10.137^{\prime}$ & & & & 5.33 & & & 1.101 & 1.217 & 3.980 & 3.237 & 13 & 18 & 10 & 13 & 7.260 & 7.360 & 7.700 & 6.810 \\
\hline 7 & Chonoki R. & $35^{\circ} 24.611^{\prime}$ & $136^{\circ} 11.902^{\prime}$ & 0.14 & 351.31 & 9.86 & 25.82 & 0 & 13 & 4.931 & 1.333 & 7.948 & 4.8 & 15 & 15 & 12 & 14 & 7.520 & 7.180 & 7.100 & 6.790 \\
\hline 8 & Ta R. & $35^{\circ} 24.025^{\prime}$ & $136^{\circ} 12.716^{\prime}$ & 0.15 & 430.07 & 11.11 & 32.61 & 0 & 25 & 5.569 & 1.043 & 5.105 & 5.090 & 15 & 15 & 13 & 14 & 7.820 & 7.290 & 6.400 & 6.670 \\
\hline 9 & Ane R. & $35^{\circ} 22.969^{\prime}$ & $136^{\circ} 13.387^{\prime}$ & 0.08 & 11.51 & 22.08 & 7.69 & 28 & 0 & 3.016 & 1.558 & 3.480 & 5.821 & 13 & 13 & 13 & 14 & 8.160 & 7.310 & 7.100 & 6.650 \\
\hline 10 & Yone R. & $35^{\circ} 21.802^{\prime}$ & $136^{\circ} 16.010^{\prime}$ & 0.10 & 23.17 & 4.90 & 25.99 & 0 & 35 & 3.828 & 1.071 & 3.538 & 7.235 & 25 & 18 & 18 & 17 & 8.430 & 8.410 & 7.400 & 6.650 \\
\hline 11 & Amano R. & $35^{\circ} 19.405^{\prime}$ & $136^{\circ} 16.057^{\prime}$ & 0.23 & 1214.29 & 58.72 & 7.44 & 23 & 0 & 4.292 & 2.951 & 2.900 & 5.382 & 15 & 20 & 15 & 16 & 8.210 & 8.720 & 8.400 & 7.250 \\
\hline 12 & Seri R. & $35^{\circ} 16.322^{\prime}$ & $136^{\circ} 14.039^{\prime}$ & 0.22 & 1076.3 & 76.30 & 9.07 & 0 & 0 & 4.640 & 2.900 & 3.248 & 5.723 & 13 & 17 & 16 & 15 & 7.990 & & 8.200 & 7.330 \\
\hline 13 & Inukami R. & $35^{\circ} 15.663^{\prime}$ & $136^{\circ} 12.860^{\prime}$ & 0.22 & 950.15 & 69.40 & 6.50 & 10 & 0 & 4.350 & 3.341 & 4.329 & 4.212 & 19 & 15 & 15 & 14 & 8.050 & 7.770 & 8.400 & 7.430 \\
\hline 14 & Ajiki R. & $35^{\circ} 15.094^{\prime}$ & $136^{\circ} 12.230^{\prime}$ & 0.21 & 830.06 & 72.24 & 7.47 & 11 & 0 & 3.654 & 3.944 & 3.527 & 4.309 & 28 & 16 & 17 & 15 & 7.360 & 7.590 & 7.500 & 6.920 \\
\hline 15 & Uso R. & $35^{\circ} 14.939^{\prime}$ & $136^{\circ} 11.881^{\prime}$ & 0.21 & 722.72 & 43.03 & 32.79 & 22 & 0 & 5.743 & 3.654 & 2.935 & 4.992 & 15 & 15 & 15 & 14 & 7.880 & 7.690 & 8.000 & 6.640 \\
\hline 16 & Bunroku R. & $35^{\circ} 14.275^{\prime}$ & $136^{\circ} 10.378^{\prime}$ & 0.20 & 597.17 & 23.28 & 6.99 & 7 & 0 & 4.002 & 2.241 & 5.105 & 4.846 & 16 & 18 & 16 & 14 & 7.760 & 7.440 & 7.500 & 6.890 \\
\hline 17 & Nomazu R. & 5013.496' & $136^{\circ} 09.118^{\prime}$ & 0.20 & 494.56 & 9.07 & 23.71 & 9 & 0 & 4.118 & 3.132 & 3.538 & 8.308 & 16 & 23 & 18 & 18 & 7.630 & 7.250 & 7.000 & 6.120 \\
\hline 18 & Echi R. & $35^{\circ} 12.803^{\prime}$ & $136^{\circ} 06.509^{\prime}$ & 0.18 & 598.94 & 40.55 & 2.06 & 0 & 0 & 2.551 & 2.319 & 4.582 & 5.675 & 15 & 13 & 14 & 14 & 7.900 & 7.790 & 8.000 & 5.520 \\
\hline 19 & Nagaso $\mathrm{R}$. & $34^{\circ} 59.772^{\prime}$ & $135^{\circ} 54.043^{\prime}$ & & & - & 0.82 & - & & 1.913 & 7.716 & 7.600 & 3.237 & 24 & 17 & 14 & 16 & 7.340 & 7.650 & 6.500 & 6.520 \\
\hline 20 & Hayama R. & $35^{\circ} 02.765^{\prime}$ & $135^{\circ} 54.453^{\prime}$ & 0.14 & 289.63 & 2.68 & 6.79 & 0 & 21 & 3.248 & 14.390 & 4.060 & 2.457 & 22 & 19 & 14 & 14 & 7.200 & 7.670 & 6.800 & 6.510 \\
\hline 21 & Shin-moriyama R. & $35^{\circ} 04.737^{\prime}$ & $135^{\circ} 56.542^{\prime}$ & 0.15 & -72.41 & 6.06 & 5.20 & 0 & 0 & 1.797 & 18.887 & 11.720 & 6.0 & 26 & 26 & 15 & 17 & 6.990 & 7.810 & 6.700 & 6.670 \\
\hline 22 & Yasu R. & $35^{\circ} 07.495^{\prime}$ & $135^{\circ} 58.443^{\prime}$ & 0.16 & 185.82 & 26.01 & 15.14 & 0 & 0 & 3.596 & 3.016 & 4.234 & 3.627 & 29 & 25 & 14 & 18 & 6.760 & 6.580 & 7.200 & 6.370 \\
\hline 23 & Yanomune R. & $35^{\circ} 08.261^{\prime}$ & $136^{\circ} 00.800^{\prime}$ & 0.19 & 527.06 & 11.72 & 7.01 & 5 & 0 & 5.458 & 3.422 & 2.881 & 6.796 & 21 & 20 & 14 & 17 & 6.850 & 6.650 & 7.000 & 6.500 \\
\hline 24 & Hino $R$. & $35^{\circ} 08.908^{\prime}$ & $136^{\circ} 01.725^{\prime}$ & 0.20 & -881.45 & 9.74 & 12.39 & 105 & 0 & 6.572 & 2.842 & 4.646 & 6.601 & 16 & 19 & 14 & 15 & 8.300 & 6.990 & 7.100 & 6.680 \\
\hline 25 & U R. & $35^{\circ} 15.685^{\prime}$ & $135^{\circ} 59.845^{\prime}$ & 0.08 & -68.06 & 14.17 & 14.91 & 14 & 0 & 1.449 & 0.869 & & 2.067 & 13 & 13 & 13 & 13 & 8.320 & 7.720 & 7.300 & 7.150 \\
\hline 26 & Wani R. & $35^{\circ} 09.254^{\prime}$ & $135^{\circ} 56.317^{\prime}$ & 0.10 & -104.75 & 1.64 & 20.17 & 38 & 0 & 2.319 & 2.721 & 1.913 & 2.749 & 14 & 13 & 15 & 13 & 8.570 & 7.820 & 7.100 & 7.000 \\
\hline 27 & Mano R. & $35^{\circ} 07.434^{\prime}$ & $135^{\circ} 56.1 \mathrm{C}$ & 0. & -65.6 & 2.8 & 22.2 & 11 & 0 & 4.06 & 2.8 & 5.105 & 2.3 & 14 & 13 & 13 & 13 & 8.5 & 7.6 & 7.700 & 6.170 \\
\hline 28 & Tenjin R. & $35^{\circ} 05.971^{\prime}$ & $135^{\circ} 55.531^{\prime}$ & 0. & 55.79 & 2.57 & 10.83 & 0 & 16 & 3.016 & 1.333 & 3.712 & 2.993 & 16 & 15 & 13 & 14 & 8.290 & 7.910 & 7.000 & 5.580 \\
\hline 29 & Fujinoki R. & $35^{\circ} 03.353^{\prime}$ & $135^{\circ} 53.729^{\prime}$ & 0.06 & -25.88 & 14.80 & 4.56 & 0 & 31 & 1.449 & 4.733 & 7.403 & 2.944 & 17 & 16 & 15 & 14 & 7.920 & 8.050 & 6.300 & 7.300 \\
\hline \multirow{2}{*}{\multicolumn{2}{|c|}{$\begin{array}{l}\text { Offshore reference site } \\
30 \quad \text { Ie- } 1\end{array}$}} & & & & & & & & & & & & & & & & & & & & \\
\hline & & $35^{\circ} 12.970^{\prime}$ & $135^{\circ} 59.959^{\prime}$ & & & & & & & 3.654 & 0.869 & 1.449 & 4.114 & & & & & & & & \\
\hline
\end{tabular}


Appendix C

Carbon and nitrogen stable isotope ratios (\%) of POM and its three potential sources (P-POM, E-POM, and R-POM) at each coastal site.

\begin{tabular}{|c|c|c|c|c|c|c|c|c|c|c|c|c|c|c|c|c|c|c|c|c|c|c|c|c|c|}
\hline \multirow{3}{*}{ Site no. } & \multirow{3}{*}{$\begin{array}{l}\text { Name of } \\
\text { tributary rivers }\end{array}$} & \multicolumn{6}{|c|}{ Nov. 2005} & \multicolumn{6}{|c|}{ Feb. 2006} & \multicolumn{6}{|c|}{ May 2006} & \multicolumn{6}{|c|}{ Jul. 2006} \\
\hline & & \multicolumn{2}{|c|}{ POM } & \multicolumn{2}{|c|}{ E-POM } & \multicolumn{2}{|c|}{ R-POM } & \multicolumn{2}{|c|}{ POM } & \multicolumn{2}{|c|}{ E-POM } & \multicolumn{2}{|c|}{ R-POM } & \multicolumn{2}{|c|}{ POM } & \multicolumn{2}{|c|}{ E-POM } & \multicolumn{2}{|c|}{ R-POM } & \multicolumn{2}{|c|}{ POM } & \multicolumn{2}{|c|}{ E-POM } & \multicolumn{2}{|c|}{ R-POM } \\
\hline & & $\delta^{15} \mathrm{~N}$ & $\delta^{13} \mathrm{C}$ & $\delta^{15} \mathrm{~N}$ & $\delta^{13} \mathrm{C}$ & $\delta^{15} \mathrm{~N}$ & $\delta^{13} \mathrm{C}$ & $\delta^{15} \mathrm{~N}$ & $\delta^{13} \mathrm{C}$ & $\delta^{15} \mathrm{~N}$ & $\delta^{13} \mathrm{C}$ & $\delta^{15} \mathrm{~N}$ & $\delta^{13} \mathrm{C}$ & $\delta^{15} \mathrm{~N}$ & $\delta^{13} \mathrm{C}$ & $\delta^{15} \mathrm{~N}$ & $\delta^{13} \mathrm{C}$ & $\delta^{15} \mathrm{~N}$ & $\delta^{13} \mathrm{C}$ & $\delta^{15} \mathrm{~N}$ & $\delta^{13} \mathrm{C}$ & $\delta^{15} \mathrm{~N}$ & $\delta^{13} \mathrm{C}$ & $\delta^{15} \mathrm{~N}$ & $\delta^{13} \mathrm{C}$ \\
\hline 1 & Kamo River & 5.47 & -24.13 & 5.23 & -11.35 & 3.52 & -28.06 & 12.26 & -29.92 & 4.90 & -21.97 & 4.15 & -25.56 & 5.47 & -25.35 & 6.25 & -17.36 & 3.76 & -28.78 & 4.42 & -24.05 & 6.73 & -9.60 & 6.63 & -30.19 \\
\hline 2 & Ado R. & 5.14 & -24.73 & & & 6.30 & -23.37 & 11.67 & -28.54 & 3.78 & -22.93 & 3.58 & -25.18 & 6.90 & -24.69 & 4.51 & -25.90 & 7.68 & -24.19 & 4.96 & -24.57 & 5.96 & -12.44 & 4.56 & -24.91 \\
\hline 3 & Ishida R. & 5.23 & -24.96 & 7.99 & -15.99 & 4.64 & -26.58 & 11.14 & -28.27 & 5.86 & -18.68 & 1.96 & -25.18 & 6.26 & -29.69 & 4.14 & -13.02 & 3.93 & -23.23 & 4.83 & -24.39 & 4.56 & -10.35 & 2.72 & -25.58 \\
\hline 4 & Momose R. & 5.48 & -25.66 & 5.00 & -9.40 & 6.69 & -29.05 & 13.21 & -28.99 & 5.15 & -14.19 & 4.27 & -27.59 & 6.39 & -30.18 & 3.76 & -15.23 & 4.97 & -27.62 & 5.36 & -24.60 & 4.79 & -12.44 & 6.26 & -28.66 \\
\hline 5 & Oura R. & 6.11 & -25.10 & 4.18 & -10.05 & 3.01 & -28.60 & 9.37 & -29.10 & 4.44 & -14.00 & 2.21 & -26.93 & 5.89 & -28.22 & 4.84 & -13.81 & 2.24 & -26.85 & 4.75 & -25.38 & 5.23 & -12.16 & 3.86 & -26.98 \\
\hline 6 & Shiotsu-o R. & 5.99 & -24.91 & 6.49 & -12.82 & 2.27 & -28.55 & 9.21 & -28.05 & 5.40 & -21.71 & 2.73 & -27.81 & 4.87 & -28.70 & 4.10 & -20.21 & 3.25 & -26.48 & 4.67 & -26.01 & 5.22 & -11.37 & 4.71 & -27.51 \\
\hline 7 & Chonoki R. & 5.20 & -24.84 & 5.95 & -18.71 & 3.56 & -26.62 & 11.90 & -29.34 & 5.07 & -20.79 & 3.93 & -26.84 & 5.01 & -27.43 & 3.89 & -22.50 & 3.68 & -28.91 & 4.55 & -25.07 & 4.00 & -16.19 & 4.16 & -27.01 \\
\hline 8 & Ta R. & 5.21 & -24.69 & 5.63 & -15.90 & 3.64 & -27.18 & 9.32 & -27.61 & & & 3.24 & -27.18 & 5.05 & -26.68 & & & 2.80 & -27.18 & 4.99 & -24.54 & & & 3.84 & -27.88 \\
\hline 9 & Ane R. & 5.26 & -24.31 & 5.33 & -6.76 & 3.79 & -26.88 & 9.32 & -28.42 & 6.19 & -13.93 & 3.08 & -26.90 & 6.27 & -27.41 & 6.18 & -15.28 & 4.27 & -23.34 & 4.75 & -24.70 & 7.26 & -10.83 & 5.95 & -25.73 \\
\hline 10 & Yone R. & 5.47 & -24.00 & 4.96 & -14.46 & 5.57 & -26.40 & 9.61 & -27.54 & 4.78 & -15.07 & 5.76 & -25.26 & 5.72 & -27.23 & & & 6.67 & -26.91 & 4.86 & -26.35 & & & 6.71 & -26.40 \\
\hline 11 & Amano R. & 5.09 & -24.14 & 4.50 & -12.72 & 5.55 & -25.57 & 6.77 & -27.78 & 6.60 & -17.69 & 5.96 & -24.39 & 5.76 & -26.87 & 5.72 & -15.40 & 5.33 & -22.77 & 4.79 & -23.77 & 7.96 & -18.08 & 6.18 & -24.77 \\
\hline 12 & Seri R. & 5.60 & -24.66 & 7.71 & -16.22 & 6.25 & -25.79 & 7.53 & -28.44 & 8.29 & -20.71 & 4.61 & -23.89 & 7.20 & -25.43 & & & 7.26 & -21.16 & 5.98 & -24.55 & 7.36 & -16.70 & 10.48 & -23.63 \\
\hline 13 & Inukami R. & 5.30 & -24.42 & 6.76 & -11.27 & 5.28 & -25.87 & 7.49 & -28.59 & 7.88 & -18.01 & 5.29 & -25.23 & 7.05 & -25.71 & 5.92 & -13.49 & 5.45 & -25.34 & 5.03 & -24.84 & 6.56 & -14.89 & 7.90 & -27.51 \\
\hline 14 & Ajiki R. & 5.64 & -25.59 & 7.44 & -16.52 & 4.87 & -28.10 & 6.90 & -28.04 & 9.65 & -27.87 & 4.90 & -27.53 & 6.71 & -25.74 & & & 6.13 & -28.57 & 5.34 & -24.27 & 9.13 & -16.42 & 6.61 & -27.88 \\
\hline 15 & Uso R. & 6.51 & -25.40 & 7.19 & -6.52 & 4.63 & -26.69 & 7.75 & -28.76 & 8.51 & -13.68 & 5.10 & -25.56 & 7.47 & -25.33 & 7.07 & -15.29 & 6.92 & -28.27 & 5.19 & -24.60 & 7.01 & -11.62 & 8.50 & -25.30 \\
\hline 16 & Bunroku R. & 6.27 & -25.26 & & & 5.78 & -27.44 & 9.46 & -29.53 & 8.52 & -16.31 & 3.89 & -26.28 & 4.99 & -26.31 & & & 5.63 & -28.54 & 5.25 & -24.52 & 9.27 & -15.09 & 6.79 & -26.56 \\
\hline 17 & Nomazu R. & 6.07 & -25.25 & & & 5.12 & -29.29 & 9.57 & -30.68 & 7.96 & -26.82 & 4.39 & -25.42 & 6.35 & -26.04 & 9.03 & -15.71 & 4.10 & -26.67 & 4.74 & -25.05 & 9.07 & -21.16 & 4.10 & -28.22 \\
\hline 18 & Echi R. & 5.73 & -25.72 & 5.18 & -13.37 & 4.01 & -28.08 & 9.41 & -29.67 & 4.75 & -21.91 & 4.75 & -25.78 & 6.38 & -26.72 & 4.33 & -21.25 & 4.61 & -19.26 & 2.95 & -26.50 & 7.36 & -16.36 & 7.22 & -20.52 \\
\hline 19 & Nagaso R. & 7.50 & -25.64 & 8.78 & -17.14 & 6.35 & -30.83 & 5.16 & -26.91 & 11.30 & -19.23 & 8.28 & -28.66 & 6.95 & -25.13 & 7.88 & -15.45 & 4.61 & -28.14 & 4.83 & -25.42 & 9.57 & -17.95 & 6.42 & -27.90 \\
\hline 20 & Hayama R. & 4.16 & -25.30 & 9.09 & -15.93 & 3.94 & -28.46 & 7.12 & -26.29 & 8.44 & -15.76 & 6.55 & -26.84 & 5.12 & -23.91 & 6.68 & -14.32 & 5.18 & -27.21 & 4.90 & -25.17 & 8.64 & -19.10 & 6.49 & -26.02 \\
\hline 21 & Shin-moriyama R. & 8.95 & -26.15 & 10.20 & -22.62 & 4.98 & -28.20 & 7.82 & -25.86 & 8.43 & -18.18 & 6.29 & -27.83 & 7.13 & -26.69 & 7.94 & -20.44 & 6.24 & -27.43 & 5.91 & -27.89 & 9.04 & -21.21 & 5.52 & -26.11 \\
\hline 22 & Yasu R. & 5.88 & -25.31 & & & 4.47 & -28.36 & 8.70 & -29.72 & & & 5.21 & -25.12 & 5.49 & -25.56 & & & 9.52 & -24.68 & 3.86 & -26.97 & & & 7.69 & -29.62 \\
\hline 23 & Yanomune R. & 7.27 & -24.99 & & & 4.26 & -27.63 & 8.38 & -29.81 & 7.17 & -17.88 & 4.48 & -26.62 & 6.32 & -26.19 & 7.04 & -21.39 & 5.30 & -26.34 & 4.81 & -25.54 & 7.28 & -21.01 & 6.25 & -26.59 \\
\hline 24 & Hino R. & 7.13 & -24.27 & 8.42 & -17.74 & 6.41 & -28.86 & 8.75 & -29.48 & 8.87 & -19.08 & 6.44 & -25.20 & 6.73 & -26.95 & 7.47 & -21.06 & 7.23 & -26.24 & 5.22 & -24.51 & 9.11 & -21.45 & 10.12 & -23.40 \\
\hline 25 & U R. & 5.64 & -26.07 & 3.90 & -11.95 & 1.64 & -29.62 & 11.65 & -27.67 & 4.77 & -19.70 & 3.84 & -27.47 & 7.21 & -24.45 & 5.07 & -14.35 & 7.26 & -26.81 & 4.02 & -24.07 & 4.22 & -13.70 & 4.06 & -28.06 \\
\hline 26 & Wani R. & 5.56 & -25.32 & 4.58 & -9.58 & 3.75 & -29.33 & 9.85 & -30.83 & 4.63 & -16.30 & 6.54 & -26.38 & 6.45 & -24.98 & 5.31 & -15.74 & 4.15 & -24.28 & 4.51 & -24.26 & 5.93 & -11.09 & 4.12 & -25.65 \\
\hline 27 & Mano R. & 6.66 & -24.64 & 4.63 & -8.73 & 4.09 & -29.87 & 7.74 & -28.66 & 5.00 & -14.21 & 3.94 & -25.52 & 7.22 & -23.82 & 5.55 & -14.86 & 2.69 & -28.75 & 4.95 & -24.12 & 6.36 & -15.59 & 8.82 & -28.99 \\
\hline 28 & Tenjin R. & 6.24 & -24.74 & 4.48 & -17.52 & 4.41 & -25.91 & 9.48 & -28.64 & 6.33 & -23.14 & 3.75 & -23.91 & 7.13 & -23.38 & 6.58 & -18.69 & 6.93 & -25.70 & 5.14 & -25.69 & 6.46 & -13.85 & 8.83 & -25.63 \\
\hline 29 & Fujinoki R. & 8.29 & -22.09 & 7.10 & -23.78 & 5.02 & -28.48 & 8.77 & -26.95 & 7.76 & -18.85 & 5.16 & -25.83 & 6.82 & -19.98 & 5.52 & -18.34 & 5.87 & -29.71 & 6.14 & -25.90 & 8.60 & -13.86 & 10.12 & -28.07 \\
\hline \multicolumn{26}{|c|}{ Offshore reference site } \\
\hline 30 & Ie-1 (offshore reference) & 5.54 & -24.65 & & & & & 12.90 & -29.44 & & & & & 7.25 & -24.38 & & & & & 5.02 & -25.00 & & & & \\
\hline
\end{tabular}




\section{Appendix D}

The relative contribution (\%) of the three potential sources (P-POM, E-POM and T-POM) to POM at each coastal site.

\begin{tabular}{|c|c|c|c|c|c|c|c|c|c|c|c|c|c|c|c|c|c|c|c|c|c|c|c|c|c|}
\hline \multirow{3}{*}{ Site no. } & \multirow{3}{*}{$\begin{array}{c}\text { Name of } \\
\text { tributary rivers }\end{array}$} & \multicolumn{6}{|c|}{ Nov. 2005} & \multicolumn{6}{|c|}{ Feb. 2006} & \multicolumn{6}{|c|}{ May 2006} & \multicolumn{6}{|c|}{ Jul. 2006} \\
\hline & & \multicolumn{2}{|c|}{ P-POM } & \multicolumn{2}{|c|}{ E-POM } & \multicolumn{2}{|c|}{ T-POM } & \multicolumn{2}{|c|}{ P-POM } & \multicolumn{2}{|c|}{ E-POM } & \multicolumn{2}{|c|}{ T-POM } & \multicolumn{2}{|c|}{ P-POM } & \multicolumn{2}{|c|}{ E-POM } & \multicolumn{2}{|c|}{ T-POM } & \multicolumn{2}{|c|}{ P-POM } & \multicolumn{2}{|c|}{ E-POM } & \multicolumn{2}{|c|}{ T-POM } \\
\hline & & Mean & Range & Mean & Range & Mean & Range & Mean & Range & Mean & Range & Mean & Range & Mean & Range & Mean & Range & Mean & Range & Mean & Range & Mean & Range & Mean & Range \\
\hline 1 & Kamo River & 91.3 & $87-96$ & 4.8 & $4-6$ & 3.8 & $0-7$ & 98.2 & $97-99$ & 0.4 & $0-1$ & 1.4 & $0-3$ & 38.2 & $35-42$ & 15.3 & $13-17$ & 46.5 & $44-49$ & 95.9 & $94-98$ & 3.2 & $2-5$ & 0.9 & $0-3$ \\
\hline 2 & Ado R. & & & & & & & 86.4 & $86-87$ & 12.0 & $10-14$ & 1.6 & $0-4$ & 38.0 & $0-86$ & 20.9 & $14-27$ & 41.1 & $0-76$ & 78.7 & $57-97$ & 3.4 & $3-4$ & 17.8 & $0-40$ \\
\hline 3 & Ishida R. & 31.1 & $0-69$ & 9.6 & $2-16$ & 59.3 & $29-85$ & 81.6 & $81-82$ & 6.2 & $5-7$ & 12.2 & $11-13$ & - & & - & & - & & 88.0 & $84-92$ & 4.5 & $4-5$ & 7.5 & $4-11$ \\
\hline 4 & Momose R. & 80.5 & $79-83$ & 0.3 & $0-1$ & 19.2 & $17-21$ & 98.7 & $98-100$ & 0.7 & $0-2$ & 0.7 & $0-2$ & - & & - & & - & & 58.0 & $47-69$ & 12.0 & $9-15$ & 30.1 & $22-38$ \\
\hline 5 & Oura R. & 99.3 & $99-100$ & 0.3 & $0-1$ & 0.3 & $0-1$ & 69.0 & $67-71$ & 0.0 & $0-0$ & 31.0 & $29-33$ & - & & - & & - & & 75.2 & $66-85$ & 0.8 & $0-2$ & 24.0 & $15-32$ \\
\hline 6 & Shiotsu-o R. & 98.1 & $96-100$ & 1.1 & $0-2$ & 0.7 & $0-2$ & 60.6 & $60-61$ & 12.3 & $11-14$ & 27.1 & $25-29$ & - & & - & & - & & 3.0 & $0-6$ & 8.7 & $8-9$ & 88.3 & $86-91$ \\
\hline 7 & Chonoki R. & 79.3 & $71-81$ & 2.8 & $0-6$ & 17.9 & $13-23$ & 90.0 & $89-91$ & 0.0 & $0-0$ & 10.0 & $9-11$ & 33.7 & $32-37$ & 0.9 & $0-3$ & 65.4 & $63-68$ & 47.3 & $36-58$ & 9.2 & $7-12$ & 43.5 & $34-53$ \\
\hline 8 & Ta R. & 79.3 & $71-87$ & 2.8 & $0-6$ & 17.9 & $13-23$ & & & & & & & & & & & & & & & & & & \\
\hline 9 & Ane R. & 80.5 & $74-87$ & 3.8 & $3-5$ & 15.7 & $10-21$ & 63.3 & $63-64$ & 0.7 & $0-1$ & 36.0 & $35-37$ & - & & - & & - & & 99.5 & $99-100$ & 0.5 & $0-1$ & 0.0 & $0-0$ \\
\hline 10 & Yone R. & 46.9 & $0-94$ & 13.2 & $6-20$ & 39.8 & $0-80$ & 54.3 & $53-55$ & 0.3 & $0-1$ & 45.5 & $44-47$ & & & & & & & & & & & & \\
\hline 11 & Amano R. & 41.3 & $0-95$ & 8.6 & $5-14$ & 50.1 & $0-91$ & 35.2 & $34-36$ & 0.4 & $0-1$ & 64.4 & $63-66$ & - & & - & & - & & 86.3 & $82-90$ & 10.2 & $9-12$ & 3.5 & $0-9$ \\
\hline 12 & Seri R. & 90.8 & $82-100$ & 1.0 & $0-2$ & 8.2 & $0-17$ & 54.0 & $54-54$ & 0.5 & $0-1$ & 45.5 & $45-46$ & & & & & & & 81.0 & $79-83$ & 2.7 & $2-4$ & 16.3 & $15-18$ \\
\hline 13 & Inukami R. & 27.2 & $0-67$ & 7.5 & $3-11$ & 65.2 & $30-91$ & 47.0 & $47-47$ & 0.0 & $0-0$ & 53.0 & $53-53$ & 45.8 & $39-55$ & 0.2 & $0-1$ & 54.0 & $45-61$ & 97.2 & $95-99$ & 1.8 & $1-3$ & 1.0 & $0-2$ \\
\hline 14 & Ajiki R. & 10.6 & $0-28$ & 19.9 & $15-23$ & 69.6 & $57-77$ & 22.7 & $20-26$ & 4.0 & $0-10$ & 73.2 & $70-76$ & & & & & & & 90.2 & $88-92$ & 8.7 & $8-9$ & 1.2 & $0-3$ \\
\hline 15 & Uso R. & 96.8 & $92-100$ & 0.7 & $0-2$ & 2.5 & $0-6$ & 49.5 & $49-50$ & 0.0 & $0-0$ & 50.5 & $50-51$ & 78.4 & $75-83$ & 0.6 & $0-2$ & 21.1 & $17-24$ & 93.5 & $91-96$ & 3.0 & $3-3$ & 3.5 & $1-6$ \\
\hline 16 & Bunroku R. & & & & & & & 72.0 & $72-72$ & 0.0 & $0-0$ & 28.0 & $28-28$ & & & & & & & 92.4 & $89-96$ & 5.2 & $4-6$ & 2.5 & $0-6$ \\
\hline 17 & Nomazu R. & & & & & & & 78.1 & $71-84$ & 12.0 & $0-29$ & 9.8 & $0-19$ & 53.5 & $53-54$ & 0.0 & $0-0$ & 46.5 & $46-47$ & 91.2 & $83-100$ & 1.1 & $0-3$ & 7.7 & $0-14$ \\
\hline 18 & Echi R. & 81.0 & $79-83$ & 0.2 & $0-1$ & 18.8 & $17-20$ & 72.3 & $71-73$ & 0.7 & $0-2$ & 27.0 & $25-29$ & - & & - & & - & & - & & - & & - & \\
\hline 19 & Nagaso R. & 2.0 & $0-6$ & 37.5 & $36-40$ & 60.5 & $57-64$ & - & & - & & - & & 82.5 & $80-85$ & 0.3 & $0-1$ & 17.2 & $15-19$ & 94.0 & $93-95$ & 0.0 & $0-0$ & 6.0 & $5-7$ \\
\hline 20 & Hayama R. & 29.2 & $0-63$ & 10.3 & $0-19$ & 60.4 & $37-81$ & 7.0 & $6-8$ & 6.5 & $6-7$ & 86.5 & $85-88$ & 1.9 & $0-6$ & 24.0 & $21-29$ & 74.1 & $71-78$ & 97.5 & $95-100$ & 0.0 & $0-0$ & 2.5 & $0-5$ \\
\hline 21 & Shin-moriyama $R$ & 0.8 & $0-2$ & 55.3 & $55-56$ & 44.0 & $43-45$ & 15.8 & $15-17$ & 23.0 & $22-24$ & 61.2 & $60-63$ & 38.0 & $36-40$ & 0.8 & $0-2$ & 61.2 & $60-62$ & 0.5 & $0-1$ & 0.0 & $0-0$ & 99.5 & $99-100$ \\
\hline 22 & Yasu R. & & & & & & & & & & & & & & & & & & & & & & & & \\
\hline 23 & Yanomune R. & & & & & & & 62.0 & $60-64$ & 0.0 & $0-0$ & 38.0 & $36-40$ & 28.1 & $24-33$ & 1.1 & $0-3$ & 70.9 & $67-73$ & 87.7 & $85-91$ & 0.2 & $0-1$ & 12.1 & $9-15$ \\
\hline 24 & Hino R. & 6.6 & $1-13$ & 38.8 & $37-41$ & 54.6 & $50-59$ & 61.5 & $61-62$ & 0.0 & $0-0$ & 38.5 & $38-39$ & 1.6 & $0-4$ & 0.4 & $0-1$ & 98.0 & $96-100$ & 91.0 & $91-91$ & 8.5 & $8-9$ & 0.5 & $0-1$ \\
\hline 25 & U R. & 85.0 & $85-85$ & 0.0 & $0-0$ & 15.0 & $15-15$ & 83.0 & $83-83$ & 16.5 & $16-17$ & 0.5 & $0-1$ & 81.6 & $63-100$ & 3.0 & $0-6$ & 15.4 & $0-31$ & 0.7 & $0-1$ & 27.7 & $27-28$ & 71.7 & $71-72$ \\
\hline 26 & Wani R. & 87.5 & $84-92$ & 0.3 & $0-1$ & 12.2 & $8-15$ & 82.0 & $81-83$ & 0.0 & $0-0$ & 18.0 & $17-19$ & 77.3 & $52-96$ & 0.2 & $0-1$ & 22.5 & $3-48$ & 25.8 & $15-38$ & 8.4 & $8-9$ & 65.8 & $54-76$ \\
\hline 27 & Mano R. & 95.6 & $92-100$ & 2.7 & $0-7$ & 1.7 & $0-5$ & 53.5 & $53-54$ & 0.0 & $0-0$ & 46.5 & $46-47$ & 94.5 & $94-95$ & 5.5 & $5-6$ & 0.0 & $0-0$ & 91.5 & $91-92$ & 8.5 & $8-9$ & 0.0 & $0-0$ \\
\hline 28 & & 100.0 & $100-100$ & 0.0 & $0-0$ & 0.0 & $0-0$ & 70.7 & $70-72$ & 2.2 & $0-5$ & 27.1 & $24-30$ & 69.5 & $56-84$ & 19.9 & $16-23$ & 10.5 & $0-22$ & 83.5 & $82-85$ & 0.0 & $0-0$ & 16.5 & $15-18$ \\
\hline 29 & Fujinoki R. & 0.5 & $0-1$ & 99.5 & $99-100$ & 0.0 & $0-0$ & 44.3 & $43-45$ & 7.0 & $6-8$ & 48.7 & $47-50$ & 36.2 & $35-38$ & 63.5 & $62-65$ & 0.3 & $0-1$ & 76.0 & $75-77$ & 0.0 & $0-0$ & 24.0 & $23-25$ \\
\hline
\end{tabular}

